\title{
Simulating ozone dry deposition at a boreal forest with a multi-layer canopy deposition model
}

\author{
Putian Zhou $^{1}$, Laurens Ganzeveld ${ }^{2}$, Üllar Rannik ${ }^{1}$, Luxi Zhou ${ }^{1, \mathrm{a}}$, Rosa Gierens ${ }^{1, \mathrm{~b}}$, Ditte Taipale ${ }^{3,4}$, \\ Ivan Mammarella ${ }^{1}$, and Michael Boy ${ }^{1}$ \\ ${ }^{1}$ University of Helsinki, Department of Physics, P.O. Box 64, University of Helsinki, 00014 Helsinki, Finland \\ ${ }^{2}$ Meteorology and Air Quality (MAQ), Department of Environmental Sciences, Wageningen University and Research Centre, \\ Wageningen, the Netherlands \\ ${ }^{3}$ University of Helsinki, Department of Forest Sciences, P.O. Box 27, University of Helsinki, 00014 Helsinki, Finland \\ ${ }^{4}$ Estonian University of Life Sciences, Department of Plant Physiology, 51014 Kreutzwaldi 1, Estonia \\ ${ }^{a}$ now at: US Environmental Protection Agency, Research Triangle Park, NC, USA \\ ${ }^{b}$ now at: Institute for Geophysics and Meteorology, University of Cologne, Cologne, Germany
}

Correspondence to: Putian Zhou (putian.zhou@ helsinki.fi)

Received: 19 February 2016 - Published in Atmos. Chem. Phys. Discuss.: 27 April 2016

Revised: 28 December 2016 - Accepted: 3 January 2017 - Published: 30 January 2017

\begin{abstract}
A multi-layer ozone $\left(\mathrm{O}_{3}\right)$ dry deposition model has been implemented into SOSAA (a model to Simulate the concentrations of Organic vapours, Sulphuric Acid and Aerosols) to improve the representation of $\mathrm{O}_{3}$ concentration and flux within and above the forest canopy in the planetary boundary layer. We aim to predict the $\mathrm{O}_{3}$ uptake by a boreal forest canopy under varying environmental conditions and analyse the influence of different factors on total $\mathrm{O}_{3}$ uptake by the canopy as well as the vertical distribution of deposition sinks inside the canopy. The newly implemented dry deposition model was validated by an extensive comparison of simulated and observed $\mathrm{O}_{3}$ turbulent fluxes and concentration profiles within and above the boreal forest canopy at SMEAR II (Station to Measure Ecosystem-Atmosphere Relations II) in Hyytiälä, Finland, in August 2010.

In this model, the fraction of wet surface on vegetation leaves was parametrised according to the ambient relative humidity (RH). Model results showed that when RH was larger than $70 \%$ the $\mathrm{O}_{3}$ uptake onto wet skin contributed $\sim 51 \%$ to the total deposition during nighttime and $\sim 19 \%$ during daytime. The overall contribution of soil uptake was estimated about $36 \%$. The contribution of sub-canopy deposition below $4.2 \mathrm{~m}$ was modelled to be $\sim 38 \%$ of the total $\mathrm{O}_{3}$ deposition during daytime, which was similar to the contribution reported in previous studies. The chemical contribution to $\mathrm{O}_{3}$ removal was evaluated directly in the model simulations. Ac-
\end{abstract}

cording to the simulated averaged diurnal cycle the net chemical production of $\mathrm{O}_{3}$ compensated up to $\sim 4 \%$ of dry deposition loss from about 06:00 to 15:00 LT. During nighttime, the net chemical loss of $\mathrm{O}_{3}$ further enhanced removal by dry deposition by a maximum $\sim 9 \%$. Thus the results indicated an overall relatively small contribution of airborne chemical processes to $\mathrm{O}_{3}$ removal at this site.

\section{Introduction}

Tropospheric ozone $\left(\mathrm{O}_{3}\right)$ is an important oxidant of many reactive species such as biogenic volatile organic compounds (BVOCs) emitted from the forest canopy (Bäck et al., 2012; Smolander et al., 2014). It also plays a significant role in the regulation of the atmospheric oxidation capacity by being one of the primary sources of the hydroxyl radical $(\mathrm{OH})$, which is the most critical oxidant in the air (Mogensen et al., 2015). $\mathrm{O}_{3}$ also initiates the formation of Criegee intermediate $(\mathrm{CI})$ radicals, which are crucial in tropospheric oxidation (Boy et al., 2013).

As an air pollutant, $\mathrm{O}_{3}$ can cause damage to human health (Kampa and Castanas, 2008) and affect ecosystem functioning via its various toxic impacts (Felzer et al., 2007). $\mathrm{O}_{3}$ can also alter the global radiative forcing as an important greenhouse gas (Stocker et al., 2013, chap. 2). Hence it is impor- 
tant to understand the $\mathrm{O}_{3}$ budget, including its sources and sinks at local or site scale, in order to understand the globalscale implications.

$\mathrm{O}_{3}$ is produced via photochemical reactions in the presence of precursor gases, e.g. volatile organic compounds (VOCs), $\mathrm{CO}$ (carbon oxide), $\mathrm{OH}$ and $\mathrm{NO}_{x}$ (nitric oxide and nitrogen dioxide), or transported downward from stratosphere and is removed mainly near the Earth's surface. For vegetated surfaces a large part of the removal process occurs via stomatal uptake on leaf surface and non-stomatal uptake on plant canopies and soil surface (Wesely, 1989; Ganzeveld and Lelieveld, 1995; Altimir et al., 2006; Rannik et al., 2012; Launiainen et al., 2013), as well as depletion by chemical reactions (Kurpius and Goldstein, 2003; Wolfe et al., 2011). In this study we focus on the $\mathrm{O}_{3}$ removal and production processes within and immediately above the canopy, more particularly on the $\mathrm{O}_{3}$ uptake by boreal forest which covers $33 \%$ of global forest land (Ruckstuhl et al., 2008).

For vegetation, the uptake of $\mathrm{O}_{3}$ depends on the turbulence intensity above and within the canopy, the diffusive transfer in the quasi-laminar boundary layer over the leaf surface, the biological properties of the plants, surface wetness condition and soil type (Ganzeveld and Lelieveld, 1995). Among them the effect of canopy wetness on $\mathrm{O}_{3}$ deposition has attracted a lot of attention in previous studies (e.g. Massman, 2004; Altimir et al., 2006). For different vegetation types and under different environmental conditions the surface wetness can enhance or reduce $\mathrm{O}_{3}$ deposition (Massman, 2004). For a boreal forest, a number of studies have revealed an enhancement of the $\mathrm{O}_{3}$ uptake under dew or high humidity conditions. For example, Lamaud et al. (2002) reported that dew on canopy surface significantly increased the $\mathrm{O}_{3}$ uptake at night and in the morning over a pine stand. Altimir et al. (2006) also found that the condensed moisture on the surfaces enhanced the non-stomatal $\mathrm{O}_{3}$ uptake in a Scots pine forest when ambient relative humidity (RH) was over 60$70 \%$. Similarly to Altimir et al. (2006), Rannik et al. (2012) revealed a strong sensitivity of the nighttime $\mathrm{O}_{3}$ uptake to $\mathrm{RH}$. The enhancement of $\mathrm{O}_{3}$ uptake on wet leaf surface has been explained by previous studies, as both the microstructure of the leaf surface and the hydrophilic compounds existing on the leaf surface are able to facilitate the formation of the water films or clusters, although the foliage surface itself is hydrophobic (Altimir et al., 2006). As a result, the different dissolved compounds like organics in the solution formed on leaf surface could react with $\mathrm{O}_{3}$ and thus enhance the $\mathrm{O}_{3}$ uptake (Altimir et al., 2006).

In addition, the boreal forest emits a large portion of BVOCs (Rinne et al., 2009), which are considered to play a significant role in non-stomatal removal of $\mathrm{O}_{3}$ by oxidation (Kurpius and Goldstein, 2003; Goldstein et al., 2004; Wolfe et al., 2011). For example, Fares et al. (2010) found the correlation between the oxidation products of monoterpenes and $\mathrm{O}_{3}$ non-stomatal flux at a ponderosa pine stand in California, USA, indicating that the gas-phase reactions of $\mathrm{O}_{3}$ with BVOCs were mostly responsible for $\mathrm{O}_{3}$ nonstomatal loss. In a model study, Wolfe et al. (2011) suggested that the non-stomatal $\mathrm{O}_{3}$ uptake at the same Californian site could be explained by considering the role of $\mathrm{O}_{3}$ destruction with the presence of very reactive BVOCs. Consequently, further analysis of the role of non-stomatal removal of $\mathrm{O}_{3}$ also strongly depends on the improvement of BVOCs measurement. However, the influence of this gas-phase chemical removal process may vary among different sites. A study by Rannik et al. (2012), who conducted a detailed analysis of a long-term $\mathrm{O}_{3}$ deposition flux measurement at the same site as in this study (Station to Measure Ecosystem-Atmosphere Relations II (SMEAR II), a boreal forest station in Hyytiälä, Finland), indicated that, at the currently known strength of BVOC emissions, the air chemistry of BVOCs was not likely an important $\mathrm{O}_{3}$ sink term at this site.

During the last 2 decades, several numerical models have been developed to study and simulate $\mathrm{O}_{3}$ dry deposition processes under different climatic and environmental conditions. Many of them have implemented the big-leaf framework following the Wesely (1989) approach, which can be coupled to regional or global models to estimate the $\mathrm{O}_{3}$ deposition flux on large scales (e.g. Hardacre et al., 2015). However, the "big-leaf" approach does not consider explicitly the role of in-canopy interactions between biogenic emissions, chemistry, turbulence and deposition. Therefore, more detailed multi-layer models including the role of these in-canopy interactions have been developed and applied to analyse incanopy deposition-related mechanisms (e.g. Ganzeveld et al., 2002b; Rannik et al., 2012; Launiainen et al., 2013). These multi-layer canopy exchange models have also been coupled to large-scale models, e.g. a global chemistry-climate model system (Ganzeveld et al., 2002a), or have been implemented in column models with detailed vertically separated layers (e.g. Wolfe and Thornton, 2011).

In this study a multi-layer $\mathrm{O}_{3}$ dry deposition model was implemented into the one-dimensional (1-D) chemical transport model SOSAA (a model to Simulate the concentrations of Organic vapours, Sulphuric Acid and Aerosols). This deposition model was based on the dry deposition representation originally described in Ganzeveld and Lelieveld (1995) and Ganzeveld et al. (1998) and implemented in the Multi-Layer Canopy CHemistry Exchange Model (MLCCHEM; Ganzeveld et al., 2002b). This canopy exchange system in MLC-CHEM was already applied in a single column model on the analysis of site-scale exchange processes (Ganzeveld et al., 2002b; Seok et al., 2013), as well as in a global chemistry-climate model system on the analysis of atmosphere-biosphere exchange processes (Ganzeveld et al., 2002a, 2010).

Furthermore, the long-term continuous measurements and extensive campaigns at SMEAR II have provided a vast amount of data with complementary information on micrometeorology as well as $\mathrm{O}_{3}$ fluxes and concentrations, which 

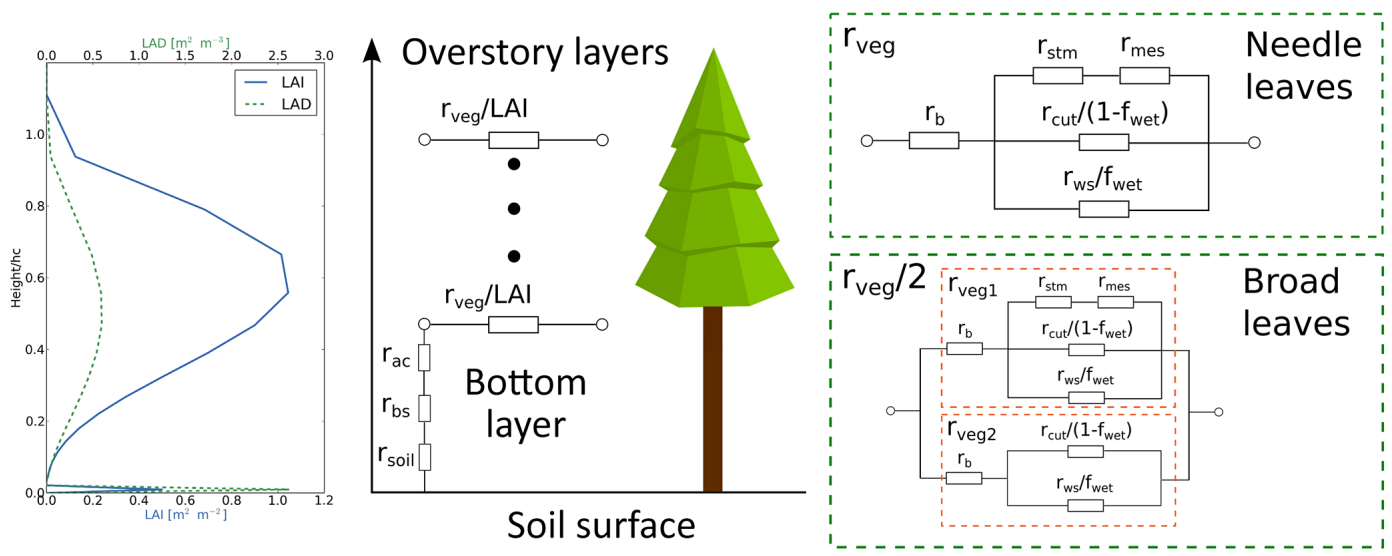

Figure 1. Vertical profiles of all-sided LAI (leaf area index) and LAD (leaf area density), as well as the diagram of resistance analogy method used in the $\mathrm{O}_{3}$ dry deposition model. The overstorey layers and the bottom layer are considered separately. The bottom layer includes the broad-leaved understorey vegetation and soil surface. $r_{\mathrm{ac}}$ is the resistance representing the turbulent transport from the reference height of the understorey vegetation to the soil surface. $r_{\mathrm{bs}}$ is the soil boundary layer resistance. $r_{\text {soil }}$ is the soil resistance. $r_{\mathrm{b}}$ is the quasi-laminar boundary layer resistance above the leaf surface. $r_{\text {veg }}$ represents the resistance to vegetation leaves, which is plotted on the right-hand side in detail. For broad leaves, the resistance to the side with $\left(r_{\mathrm{veg} 1}\right)$ or without $\left(r_{\mathrm{veg} 2}\right)$ stomata is computed separately. $r_{\mathrm{stm}}$ is the stomatal resistance and $r_{\text {mes }}$ is the mesophyllic resistance. $r_{\text {cut }}$ is the cuticle resistance and $r_{\mathrm{ws}}$ is the resistance to wet skin. $f_{\text {wet }}$ is the wet skin fraction. All the variables are defined for each layer. Note that here LAI is the all-sided leaf area index for each layer. The symbols are also explained in the text and Table A1.

are highly appropriate for validating the new model and investigating more detailed processes. We selected a featured month August 2010 for such an extensive evaluation of the model because this month was characterised by exceptional hot and dry conditions in the first 2 weeks, which possibly represented a future climate at this site (Williams et al., 2011), then followed by 2 cooler weeks. This study is a starting point of investigating gas dry deposition processes by using SOSAA. We aim to evaluate not only quantitatively $\mathrm{O}_{3}$ fluxes and concentration profiles but also the role of individual deposition processes at this site. This is a prerequisite for a further analysis of BVOCs deposition and chemistry in the follow-up research.

In the following section, a detailed description of the measurement and model will be shown. The comparisons between simulated and observed meteorological quantities, $\mathrm{O}_{3}$ fluxes above the canopy and $\mathrm{O}_{3}$ concentration profiles are described in Sect. 3, as well as the discussion about $\mathrm{O}_{3}$ flux profiles and the impact of air chemistry. Finally, a summary is given in Sect. 4.

\section{Methods}

\subsection{Site}

All the measurement data used in this study were from SMEAR II located in Hyytiälä, Finland $\left(61^{\circ} 51^{\prime} \mathrm{N}, 24^{\circ} 17^{\prime} \mathrm{E}\right.$; 181 m a.s.1.) (Hari and Kulmala, 2005). The boreal coniferous forest is relatively homogeneous around the station in all the directions within $200 \mathrm{~m}, 75 \%$ covered by Scots pine
(Pinus sylvestris) and the rest covered by Norway Spruces (Picea abies) and deciduous trees (Bäck et al., 2012). The understorey vegetation mainly consists of lingonberry (Vaccinium vitis-idaea) and bilberry (Vaccinium myrtillus) with a mean height of $0.2-0.3 \mathrm{~m}$. The forest floor is covered by dense mosses, mostly Dicranum polysetum, Hylocomium splendens and Pleurozium schreberi. Underneath is a $5 \mathrm{~cm}$ layer of humus in soil (Kolari et al., 2006; Kulmala et al., 2008). In 2010, the tree height reaches around $18 \mathrm{~m}$. The all-sided leaf area index (LAI) is about $7.5 \mathrm{~m}^{2} \mathrm{~m}^{-2}$, including $\sim 6.0 \mathrm{~m}^{2} \mathrm{~m}^{-2}$ overstorey vegetation, $\sim 0.5 \mathrm{~m}^{2} \mathrm{~m}^{-2}$ understorey vegetation and $\sim 1 \mathrm{~m}^{2} \mathrm{~m}^{-2}$ moss layer (Launiainen et al., 2013). The vertical profiles of LAI and leaf area density (LAD) are shown in Fig. 1.

\subsection{Measurements}

The measurement data at SMEAR II are currently publicly available in the data server maintained by AVAA open data publishing platform (http://avaa.tdata.fi/web/smart/smear), which was originally introduced in Junninen et al. (2009). Several observed quantities used in this study are available at 4.2, 8.4, 16.8, 33.6, 50.4 and $67.2 \mathrm{~m}$ a.g.l., including air temperature (measured by Pt100 sensor), air water content (LI-COR LI-840 infrared light absorption analyser) and $\mathrm{O}_{3}$ concentration (TEI 49C ultraviolet light absorption analyser). Other observed quantities include the photosynthetically active radiation (PAR, 400-700 nm) (LI-COR Li190SZ quantum sensor) measured at $18 \mathrm{~m}$, PAR (array of four LI-COR Li-190SZ sensors) measured at $0.6 \mathrm{~m}$, net radiation (Reeman MB-1 net radiometer) at $67 \mathrm{~m}, \mathrm{O}_{3}$ flux 
(Gill Solent HS 1199 sonic anemometer and Unisearch Associates LOZ-3 gas analyzer) at $23 \mathrm{~m}$, friction velocity (Gill Solent $1012 \mathrm{R}$ anemometer/thermometer) at $23 \mathrm{~m}$, sensible and latent heat fluxes ( $H$ and LE) (Gill Solent 1012R and LICOR LI-6262 gas analyzer) at $23 \mathrm{~m}$ and soil heat flux (Hukseflux HFP01 heat flux sensors).

In this study the measured $\mathrm{O}_{3}$ fluxes were calculated over $30 \mathrm{~min}$ averaging period using the EddyUH software (Mammarella et al., 2016) and according to standard methodology (for more details see Rannik et al., 2012). Other variables were also half-hour averaged to fit the model time step for both input and output. The air temperature $(T), \mathrm{RH}$ and $\mathrm{O}_{3}$ concentration were linearly interpolated using the observations collected at a height of 16.8 and $33.6 \mathrm{~m}$ to arrive at the estimated parameter values at $23 \mathrm{~m}$ to allow a direct comparison of the model results with the measurements or being used as input for the model. The missing observed data points of $T, \mathrm{RH}$ and $\mathrm{O}_{3}$ were gap-filled with the method described in Gierens et al. (2014).

The measured $\mathrm{O}_{3}$ fluxes were filtered based on the fact that previous studies showed that the measured fluxes had large errors under very low turbulence (Rannik et al., 2006). The threshold of such low turbulence conditions was usually set according to the measured friction velocity on top of the canopy in the range of 0.1 to $0.25 \mathrm{~m} \mathrm{~s}^{-1}$ (Altimir et al., 2006; Rannik et al., 2012; Launiainen et al., 2013). Here the observed $\mathrm{O}_{3}$ fluxes were excluded when $u_{*} \leqslant 0.2 \mathrm{~m} \mathrm{~s}^{-1}$, which was proposed by Rannik et al. (2012). In addition, the $\mathrm{O}_{3}$ flux measurements were filtered out when precipitation occurred within preceding $1 \mathrm{~h}$. Previous studies used a more strict criteria for such a filter that the preceding $12 \mathrm{~h}$ should keep dry to ensure dry canopy conditions (Altimir et al., 2006; Launiainen et al., 2013). However, in this study the fraction of wet canopy skin was taken into account and consequently we applied the filtering criteria of $1 \mathrm{~h}$. Overall, $60 \%$ of $\mathrm{O}_{3}$ flux data were available compared to $87 \%$ prior to filtering.

Here we should notice that the fluxes determined by the eddy-covariance (EC) technique were affected by the stochastic nature of turbulence, revealing as the random uncertainty of $30 \mathrm{~min}$ average fluxes. For the EC measurement the random uncertainty was typically on the order of 10 to a few tens of percent. For the $\mathrm{O}_{3}$ turbulent flux measurement at the same site Keronen et al. (2003) presented the random error statistics, defined as 1 standard deviation of the random uncertainty of turbulent flux, ranging from about 10 to $40 \%$.

\subsection{Classification of time period}

Previous studies showed that in pine forest RH could enhance non-stomatal $\mathrm{O}_{3}$ uptake (Lamaud et al., 2002; Altimir et al., 2006; Rannik et al., 2012), especially during nighttime (Rannik et al., 2012). Hence in order to further analyse the impact of $\mathrm{RH}$, the data were separated into different groups according to daytime (D) and nighttime (N) as well as RH measured inside the canopy, representing the daytime with high humidity condition (DH), daytime with low humidity condition (DL), nighttime with high humidity condition (NH) and nighttime with low humidity condition (NL). The data points were considered as daytime when the sun elevation angle was larger than $10^{\circ}$ and as nighttime when the sun elevation angle was smaller than $0^{\circ}$. The $\mathrm{RH}$ threshold value was set to $70 \%$ as in previous studies (Altimir et al., 2006; Rannik et al., 2012), so a period is in high humidity condition when all the measured $\mathrm{RH}$ values inside the canopy are higher than $70 \%$ and a period is in low humidity condition when all the measured RH values inside the canopy are lower than $70 \%$. For $\mathrm{O}_{3}$ flux, "all" was used to represent the time period with all available data after filtering described in section 2.2.

\subsection{Model description}

\subsubsection{SOSAA}

SOSAA is a 1-D chemical transport model which couples different modules to simulate the emissions of BVOCs, chemical reactions of organic and inorganic compounds in the air, transportation of trace gases and aerosol particles, as well as the aerosol processes within and above the canopy in the planetary boundary layer. It was first introduced as SOSA by Boy et al. (2011) based on the 1-D version of SCADIS (SCAlar DIStribution; Sogachev et al., 2002). After that an aerosol module based on UHMA (University of Helsinki Multicomponent Aerosol model; Korhonen et al., 2004) was implemented by Zhou et al. (2014), resulting in its name being changed to SOSAA. The current version of SOSAA includes five modules. The meteorology module is based on SCADIS. Emissions of BVOCs from the canopy are calculated by the Model of Emissions of Gases and Aerosols from Nature (MEGAN; Guenther et al., 2006). The Master Chemical Mechanism version 3.2 (MCMv3.2) (http: $/ /$ mcm.leeds.ac.uk/MCM) has been implemented to provide chemistry information. The nucleation, condensation, coagulation and deposition of aerosol particles are described by UHMA. In this study a gaseous compound dry deposition module has been implemented into SOSAA. SOSAA has already been applied and verified in several studies (e.g. Kurtén et al., 2011; Mogensen et al., 2011, 2015; Boy et al., 2013; Bäck et al., 2012; Smolander et al., 2014; Zhou et al., 2015).

In SOSAA, the horizontal wind velocity ( $u$ and $v$ ), $T$, specific humidity $\left(q_{v}\right)$, turbulent kinetic energy (TKE) and the specific dissipation of TKE $(\omega)$ are computed every time step (10 s) by prognostic equations. In order to represent the local to synoptic-scale effects, $u, v, T$ and $q_{v}$ near and within the canopy are nudged to local measurement data at SMEAR II station with a nudging factor of 0.01 . A TKE- $\omega$ parametrisation scheme is used to calculate the turbulent diffusion coefficient $\left(K_{\mathrm{t}}\right)$ (Sogachev, 2009): 
$K_{\mathrm{t}}=C_{\mu} \frac{\mathrm{TKE}}{\omega}$

$\omega=\frac{\varepsilon}{\mathrm{TKE}}$,

where $\varepsilon$ is the dissipation rate of TKE and $C_{\mu}(0.0436)$ is a closure constant. Hence the turbulent flux of a quantity $X\left(F_{\mathrm{t}, X}\right)$ can be computed as

$F_{\mathrm{t}, X}=-K_{\mathrm{t}} \frac{\partial X}{\partial z}$

where upward fluxes are positive and vice versa. Specifically, the $H$ and LE at each model layer are computed as

$H=-C_{\mathrm{p}, \text { air }} \rho_{\text {air }} K_{\mathrm{h}}\left(\frac{\partial T}{\partial z}+\gamma_{\mathrm{d}}\right)$,

$\mathrm{LE}=-L_{\mathrm{v}} K_{\mathrm{h}} \frac{\partial q_{v}}{\partial z}$,

where $C_{\mathrm{p} \text {,air }}\left(1009.0 \mathrm{~J} \mathrm{~kg}^{-1} \mathrm{~K}^{-1}\right)$ is the specific heat capacity at constant pressure. $\rho_{\text {air }}\left(1.205 \mathrm{~kg} \mathrm{~m}^{-3}\right)$ is the air density, which is a constant in the model. $\gamma_{\mathrm{d}}\left(0.0098 \mathrm{~K} \mathrm{~m}^{-1}\right)$ is the lapse rate of dry air. $L_{\mathrm{v}}\left(2.256 \times 10^{6} \mathrm{~J} \mathrm{~kg}^{-1}\right)$ is the latent heat of vaporisation for water. $K_{\mathrm{h}}$ is the turbulent eddy diffusivity for heat fluxes, which is derived from $K_{\mathrm{t}}$ according to the atmospheric stability.

The upper boundary values of $u, v, T$ and $q_{v}$ are constrained by the ERA-Interim reanalysis dataset provided by the European Centre for Medium-Range Weather Forecasts (ECMWF; Dee et al., 2011). Above the canopy, the incoming direct and diffuse global radiations measured at SMEAR II station, and the long-wave radiation obtained from the ERAInterim dataset are read in to improve the energy balance closure. Then the reflection, absorption, penetration and emission of three bands of radiation (long-wave, near-infrared and PAR) at each layer inside the canopy are explicitly computed according to the radiation scheme proposed by Sogachev et al. (2002). At the lower boundary, the measured soil heat flux at SMEAR II is used to further improve the representation of surface energy balance. All the input data are interpolated to match the model time for each time step. With the input data, the mass and energy exchange between atmosphere and plant cover (including the soil underneath) and the radiation attenuation inside the canopy are optimal to simulate the micrometeorological drivers of $\mathrm{O}_{3}$ deposition at this site.

In current SOSAA, a modified version of MEGAN has been used to simulate the emissions of BVOCs from the trees. The emissions of some important BVOCs are included, e.g. monoterpenes ( $\alpha$-pinene, $\beta$-pinene, $\Delta^{3}$-carene, limonene, cineol and other minor monoterpenes - OMT), sesquiterpenes (farnesene, $\beta$-caryophyllene and other minor sesquiterpenes - OSQ) and 2-methyl-3-buten-2-ol (MBO). The chemistry mechanism is from MCMv3.2, including necessary inorganic reactions and the full MCM oxidation paths for methane $\left(\mathrm{CH}_{4}\right)$, isoprene, MBO, $\alpha$-pinene, $\beta$-pinene, limonene and $\beta$-caryophyllene. We have also included the first-order oxidation reactions with $\mathrm{OH}, \mathrm{O}_{3}, \mathrm{NO}_{3}$ for cineole, $\Delta^{3}$-carene, OMT, farnesene and OSQ. The related chemical reactions of stabilised Criegee intermediates (sCIs) with updated reaction rates from Boy et al. (2013) are also taken into account in current simulations. For more details about emissions and chemistry we refer to Mogensen et al. (2015).

\subsubsection{Multi-layer $\mathrm{O}_{3}$ dry deposition model}

A gas dry deposition model has been implemented into SOSAA to investigate the influence of the dry deposition processes on the atmosphere-biosphere gas exchange and incanopy gas concentrations. In this study we focus on the $\mathrm{O}_{3}$ dry deposition since it is the basis of calculating the uptake of other trace gases, including BVOCs (Wesely, 1989). In this multi-layer dry deposition model the $\mathrm{O}_{3}$ deposition flux is calculated at each layer as

$F_{i}=-\left[\mathrm{O}_{3}\right]_{i} \cdot V_{\mathrm{d}, i} \quad(i=1, \ldots, N)$,

where $F$ is the $\mathrm{O}_{3}$ deposition flux $\left(\mu \mathrm{g} \mathrm{m}^{-2} \mathrm{~s}^{-1}\right),\left[\mathrm{O}_{3}\right]$ is the $\mathrm{O}_{3}$ concentration $\left(\mu \mathrm{g} \mathrm{m}^{-3}\right)$ and $V_{\mathrm{d}}$ is the layer-specific conductance $\left(\mathrm{m} \mathrm{s}^{-1}\right)$. The subscript $i$ represents layer index. Layer 1 is the bottom layer including the soil surface and the understorey vegetation where the moss layer is considered as part of the soil surface for simplicity. The overstorey layers 2 to $N$ include only vegetation surface, where $N$ is the layer index at the canopy top.

$V_{\mathrm{d}}$ is calculated for bottom layer (layer 1) and overstorey layers (layers 2 to $N$ ) differently. In addition, the deposition onto dry and wet parts of the leaf surface is considered separately. In overstorey layers, only the deposition onto leaves is taken into account, while in the bottom layer the additional pathway of deposition onto the soil surface exists. Thus,

$$
\begin{aligned}
& V_{\mathrm{d}, i}=\mathrm{LAI}_{i} V_{\mathrm{dveg}, i}+\delta_{i 1} V_{\mathrm{dsoil}}, \\
& V_{\mathrm{dveg}, i}=\frac{1}{r_{\mathrm{veg}, i}}, \\
& V_{\mathrm{dsoil}}=\frac{1}{r_{\mathrm{ac}}+r_{\mathrm{bs}}+r_{\text {soil }}} .
\end{aligned}
$$

Here $\mathrm{LAI}_{i}$ is the all-sided leaf area index for each layer $\left(\mathrm{m}^{2} \mathrm{~m}^{-2}\right)$. The Kronecker delta $\delta_{i 1} \quad\left(\delta_{i 1}=1\right.$ when $i=1$; $\delta_{i 1}=0$ when $i \neq 1$ ) is introduced here to simplify the formula. $V_{\mathrm{dveg}, i}$ is the layer-specific leaf surface conductance and $V_{\text {dsoil }}$ is the soil conductance.

$r_{\mathrm{veg}}$ is the leaf surface resistance which represents how $\mathrm{O}_{3}$ finally deposits onto different parts of leaf surface (Fig. 1). It can be calculated at each layer for needle leaves as

$r_{\mathrm{veg}}=r_{\mathrm{b}}+\frac{1}{1 /\left(r_{\mathrm{stm}}+r_{\mathrm{mes}}\right)+\left(1-f_{\mathrm{wet}}\right) / r_{\mathrm{cut}}+f_{\mathrm{wet}} / r_{\mathrm{ws}}}$.

For broad leaves, $\mathrm{O}_{3}$ can deposit on a side without stomata or a side with stomata, and hence $r_{\mathrm{veg}}$ is computed in a different way as 


$$
\begin{aligned}
& r_{\mathrm{veg}}=2 /\left(\frac{1}{r_{\mathrm{veg} 1}}+\frac{1}{r_{\mathrm{veg} 2}}\right), \\
& r_{\mathrm{veg} 1}=r_{\mathrm{b}}+\frac{1}{\left(1-f_{\mathrm{wet}}\right) / r_{\mathrm{cut}}+f_{\mathrm{wet}} / r_{\mathrm{ws}}}, \\
& r_{\mathrm{veg} 2}=r_{\mathrm{b}}+\frac{1}{1 /\left(r_{\mathrm{stm}}+r_{\mathrm{mes}}\right)+\left(1-f_{\mathrm{wet}}\right) / r_{\mathrm{cut}}+f_{\mathrm{wet}} / r_{\mathrm{ws}}} .
\end{aligned}
$$

Here $r_{\mathrm{b}}$ is the quasi-laminar boundary layer resistance over the leaf surface, which depends on molecular diffusivity and horizontal wind speed (Meyers, 1987), and $r_{\text {stm }}$ is the stomatal resistance which is derived from the stomatal resistance for water vapour $\left(r_{\mathrm{stm}, \mathrm{H}_{2} \mathrm{O}}\right)$ by using a factor of the molecular diffusivity ratio:

$r_{\mathrm{stm}}=\frac{D_{\mathrm{H}_{2} \mathrm{O}}}{D_{\mathrm{O}_{3}}} r_{\mathrm{stm}, \mathrm{H}_{2} \mathrm{O}}$.

Here $D_{\mathrm{H}_{2} \mathrm{O}}$ and $D_{\mathrm{O}_{3}}$ are the molecular diffusivities of water vapour and $\mathrm{O}_{3}$, respectively. $r_{\mathrm{stm}, \mathrm{H}_{2} \mathrm{O}}$ is computed by SCADIS module in SOSAA and also used to calculate LE and thus the energy balance (Sogachev et al., 2002). $r_{\text {mes }}$ is the mesophyllic resistance, which can be ignored for $\mathrm{O}_{3}\left(0 \mathrm{~s} \mathrm{~m}^{-1}\right) . r_{\text {cut }}\left(10^{5} \mathrm{~s} \mathrm{~m}^{-1}\right)$ is the cuticle resistance and $r_{\mathrm{ws}}\left(2000 \mathrm{~s} \mathrm{~m}^{-1}\right)$ represents the uptake on leaf wet skin. Their values are taken from Ganzeveld and Lelieveld (1995). Canopy wetness is represented by the fraction of wet skin $f_{\text {wet }}$, which is determined by RH (Lammel, 1999; Wu et al., 2003):

$f_{\text {wet }}= \begin{cases}1 & 0.9 \leqslant \mathrm{RH} \\ \frac{\mathrm{RH}-0.7}{0.2} & 0.7 \leqslant \mathrm{RH}<0.9 . \\ 0 & \mathrm{RH}<0.7\end{cases}$

The threshold $70 \%$ is suggested by Altimir et al. (2006).

$r_{\mathrm{ac}}$ is the resistance representing the turbulent transport from the reference height of the understorey vegetation to the soil surface. Since the gas transport is explicitly calculated in SOSAA and the bottom layer height is only $\sim 0.3 \mathrm{~m}$, the turbulence resistance between vegetation and ground is expected not to be an important factor for soil deposition, and consequently we have set $r_{\mathrm{ac}}$ to zero. $r_{\mathrm{bs}}$ is the soil boundary layer resistance which is calculated as (Nemitz et al., 2000; Launiainen et al., 2013)

$r_{\mathrm{bs}}=\frac{S c-\ln \left(\delta_{0} / z_{*}\right)}{\kappa u_{* \mathrm{~g}}}$.

Here $S c$ (1.07) is the Schmidt number for $\mathrm{O}_{3} . \kappa$ is the von Kármán constant $(0.41) . \delta_{0}=D_{\mathrm{O}_{3}} /\left(\kappa u_{* \mathrm{~g}}\right)$ is the height above ground where the molecular diffusivity is equal to turbulent eddy diffusivity. $z_{*}(0.1 \mathrm{~m})$ is the height under which the logarithmic wind profile is assumed. $u_{* \mathrm{~g}}$ is the friction velocity near the ground. $r_{\text {soil }}$ is the soil resistance; $400 \mathrm{~s} \mathrm{~m}^{-1}$ is used here according to Ganzeveld and Lelieveld (1995). A

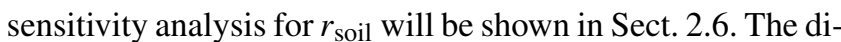
agram of the resistance analogy parametrisation method described above is shown in Fig. 1. All the symbols are also explained and listed in Table A1.

In the model the evolution of $\mathrm{O}_{3}$ concentration is calculated for each layer by the prognostic equation

$$
\begin{aligned}
\frac{\partial\left[\mathrm{O}_{3}\right]}{\partial t} & =\frac{\partial}{\partial z}\left(K_{\mathrm{t}} \frac{\partial\left[\mathrm{O}_{3}\right]}{\partial z}\right)-\left(V_{\mathrm{dveg}} \mathrm{LAD}+V_{\mathrm{dsoil}} A_{\mathrm{s}}\right)\left[\mathrm{O}_{3}\right] \\
& +Q_{\text {chem }}
\end{aligned}
$$

where the first term on the right-hand side represents the vertical mixing of $\mathrm{O}_{3}$. The second term is the sink by dry deposition, which is non-zero only inside the canopy. The last one is chemistry production and loss of $\mathrm{O}_{3}$ for each model layer. $A_{\mathrm{S}}\left(\mathrm{m}^{2} \mathrm{~m}^{-3}\right)$ is the soil area index, which is the ratio between soil area and the model grid volume; hence it is non-zero only at the bottom layer, which includes the soil surface. All the other chemical compounds are also computed following this prognostic equation. According to Eq. (3) the $\mathrm{O}_{3}$ turbulent flux $F_{\mathrm{t}}$ in the model can be obtained as

$F_{\mathrm{t}}=-K_{\mathrm{t}} \frac{\partial\left[\mathrm{O}_{3}\right]}{\partial z}$

\subsection{Model set-up}

In this study the newly implemented $\mathrm{O}_{3}$ dry deposition module was applied to simulate the time period from 1 to $31 \mathrm{Au}$ gust 2010 (Julian day 213 to 243). The model column domain was set from $0 \mathrm{~m}$ at ground surface up to $3000 \mathrm{~m}$ with 51 layers logarithmically configured, including the whole planetary boundary layer and part of the free atmosphere on top of it. We also constrained the model with the site-specific vegetation cover properties as presented before in Sect. 2.1. The overstorey layers only included needle-leaved part of Scots pine trees above $\sim 0.3 \mathrm{~m}$. Below that there was the understorey vegetation and ground surface. Since the understorey consisted of vegetation with leaves instead of needles, the parametrisation method for the understorey vegetation was considered the same as that for broad-leaved species. In order to secure a more accurate representation of canopy wetness which was also relevant to the calculation of the layerspecific conductance for $\mathrm{O}_{3}$, $\mathrm{RH}$ values inside the canopy were calculated from the measured absolute humidity and simulated air temperature.

In addition, to secure a realistic simulation of $\mathrm{O}_{3}$ in a column model like SOSAA we also forced the model's $\mathrm{O}_{3}$ concentration at $23 \mathrm{~m}$ to resemble the observed value every time step; the $\mathrm{O}_{3}$ concentrations at other levels were then calculated by Eq. (17). In this way, we implicitly added the role of advection in determining the $\mathrm{O}_{3}$ concentration above the canopy. The gap-filled observed values which were used for the forcing are shown in Fig. $2 b$.

Several sensitivity cases have been conducted in this study (Table 1). In the case BASE all the parameters and 

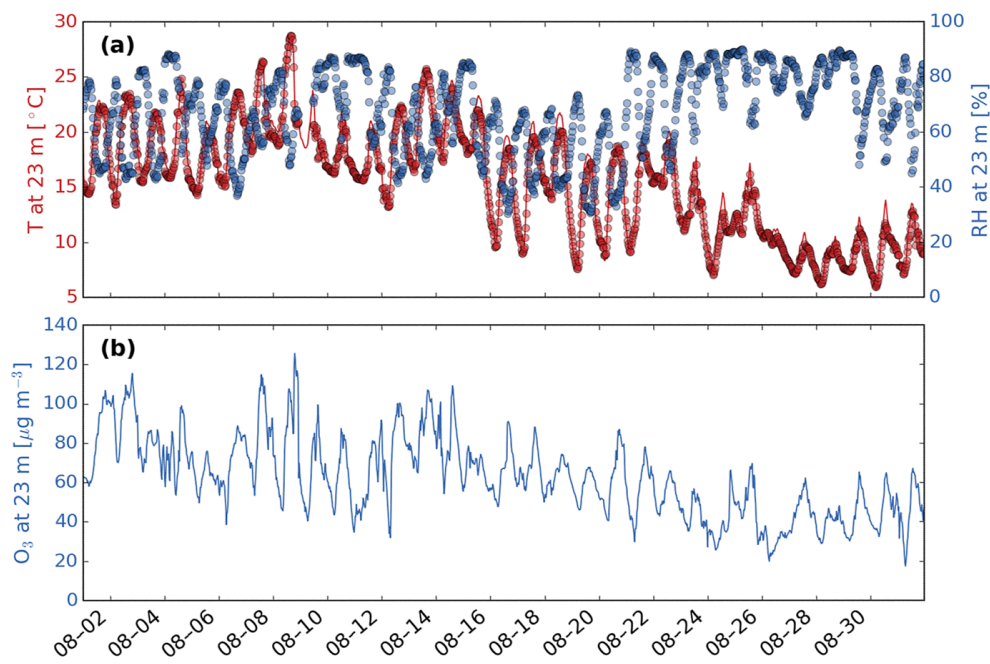

Figure 2. (a) Modelled (solid line) and measured (dots) time series of air temperature $(T$, red) and the measured ambient relative humidity (RH, blue) at $23 \mathrm{~m}$ above the ground. (b) Measured $\mathrm{O}_{3}$ concentration (blue) at $23 \mathrm{~m}$ above the ground. The time period is August 2010.

methods were kept the same as described in Sect. 2.4. In cases RSOIL200, RSOIL600 and RSOIL800 $r_{\text {soil }}$ was altered to 200,600 and $800 \mathrm{~s} \mathrm{~m}^{-1}$, respectively. In the case FREEO3, the $\mathrm{O}_{3}$ concentration at $23 \mathrm{~m}$ was computed from Eq. (17) instead of being set to the measurement data.

\subsection{Sensitivity analysis of $r_{\text {soil }}$}

$r_{\text {soil }}$ varied in different studies, ranging from 10 to $180 \mathrm{~s} \mathrm{~m}^{-1}$ for dry soil and 180 to $1100 \mathrm{~s} \mathrm{~m}^{-1}$ for wet soil (Massman, 2004). In this study the dry deposition module was developed on the basis of the model from Ganzeveld and Lelieveld (1995) in which $r_{\text {soil }}$ was $400 \mathrm{~s} \mathrm{~m}^{-1}$. In order to assess the uncertainties involved in estimating $r_{\text {soil }}$, different values of $r_{\text {soil }}$ ranging from 200 to $800 \mathrm{~s} \mathrm{~m}^{-1}$ were tested in this study (Table 2). As can be expected, the modelled $\mathrm{O}_{3}$ fluxes decrease as $r_{\text {soil }}$ increases. The BASE case shows the best performance in general, although it overestimates $\sim 16 \%$ nighttime $\mathrm{O}_{3}$ fluxes. Since the RSOIL200 case overestimates $\mathrm{O}_{3}$ fluxes by $\sim 17 \%$ in average for the whole month, $\sim 12 \%$ at daytime and $\sim 35 \%$ at nighttime, the RSOIL200 sensitivity case indicates that using this lower estimate, a value that might be more appropriate for high organic (and dry) soils, seems not to represent properly the role of soil removal at this site. However, taking higher resistance values, e.g. one of 600 or $800 \mathrm{~s} \mathrm{~m}^{-1}$, seems to result in a better simulation of the role of the soil uptake at nighttime. However, considering the overall performance and better estimation of daytime $\mathrm{O}_{3}$ fluxes, we used $400 \mathrm{~s} \mathrm{~m}^{-1}$ as the soil resistance in this study.
Table 1. Table of sensitivity cases. The case names and their short description texts are shown.

\begin{tabular}{ll}
\hline Name & Description \\
\hline BASE & the same as described in Sect. 2.4 \\
RSOIL200 & $r_{\text {soil }}=200 \mathrm{~s} \mathrm{~m}^{-1}$ \\
RSOIL600 & $r_{\text {soil }}=600 \mathrm{~s} \mathrm{~m}^{-1}$ \\
RSOIL800 & $r_{\text {soil }}=800 \mathrm{~s} \mathrm{~m}^{-1}$ \\
FREEO3 & $\begin{array}{l}\mathrm{O}_{3} \text { concentration at 23 m was also computed } \\
\text { instead of using observed data }\end{array}$ \\
\hline
\end{tabular}

\section{Results and discussion}

\subsection{Micrometeorology}

The simulated month was warm and dry with little precipitation. Moreover, the temperature decreased dramatically in the middle of the month. In the first half of month ( 1 to 15 August) the average temperature at $23 \mathrm{~m}$ was $19.0^{\circ} \mathrm{C}$, while it dropped to $12.1{ }^{\circ} \mathrm{C}$ in the second half of month (16 to 31 August) (Fig. 2a). Analysis of the full temperature record indicated that this transition in the weather conditions at the site was well simulated by the model. RH varied inversely with air temperature. Its average value increased only slightly from $66.0 \%$ in the first half of the month to $69.3 \%$ in the second half. However, a dramatic increase of daily mean $\mathrm{RH}$ values from 49.3 to $73.5 \%$ occurred between 20 and $21 \mathrm{Au}-$ gust (Fig. 2a). The combination of the dry weather and the large variation of temperature provided a good sample for verifying the $\mathrm{O}_{3}$ dry deposition module.

Figure 3 shows the comparison results between simulated and measured horizontal wind speed and friction velocity $\left(u_{*}\right)$. Both of them are essential for estimating the 
Table 2. The average (mean) and standard deviation (SD) of modelled and measured $\mathrm{O}_{3}$ fluxes $\left(\mu \mathrm{g} \mathrm{m}^{-2} \mathrm{~s}^{-1}\right)$ above the canopy during different time periods (All for the whole month, $\mathrm{D}$ for daytime, $\mathrm{N}$ for nighttime) for different cases (OBS for measurement, BASE for basic settings used in this study, RSOIL200 uses the same settings as in BASE except $r_{\text {soil }}=200 \mathrm{~s} \mathrm{~m}^{-1}$, similarly, RSOIL600 with $r_{\text {soil }}=600 \mathrm{~s} \mathrm{~m}^{-1}$ and RSOIL800 with $r_{\text {soil }}=800 \mathrm{~s} \mathrm{~m}^{-1}$ ) are shown. The relative error (RE) of modelled $\mathrm{O}_{3}$ flux compared to the observation $\left(F_{\mathrm{t}, \text { mod }}-F_{\mathrm{t}, \mathrm{obs}}\right) / F_{\mathrm{t}, \mathrm{obs}}$ is also presented.

\begin{tabular}{|c|c|c|c|c|c|c|}
\hline \multirow[t]{2}{*}{ Cases } & \multicolumn{2}{|c|}{ All } & \multicolumn{2}{|l|}{$\mathrm{D}$} & \multicolumn{2}{|l|}{$\mathrm{N}$} \\
\hline & Mean \pm SD & RE & Mean \pm SD & $\mathrm{RE}$ & Mean $\pm \mathrm{SD}$ & RE \\
\hline OBS & $0.246 \pm 0.175$ & & $0.334 \pm 0.165$ & & $0.103 \pm 0.073$ & \\
\hline RSOIL200 & $0.286 \pm 0.173$ & $+16.4 \%$ & $0.375 \pm 0.162$ & $+12.1 \%$ & $0.140 \pm 0.067$ & $+35.0 \%$ \\
\hline BASE & $0.250 \pm 0.153$ & $+1.77 \%$ & $0.329 \pm 0.143$ & $-1.74 \%$ & $0.120 \pm 0.059$ & $+16.2 \%$ \\
\hline RSOIL600 & $0.231 \pm 0.144$ & $-6.00 \%$ & $0.305 \pm 0.134$ & $-8.85 \%$ & $0.109 \pm 0.057$ & $+5.16 \%$ \\
\hline RSOIL800 & $0.219 \pm 0.139$ & $-10.8 \%$ & $0.290 \pm 0.129$ & $-13.2 \%$ & $0.101 \pm 0.055$ & $-2.17 \%$ \\
\hline
\end{tabular}
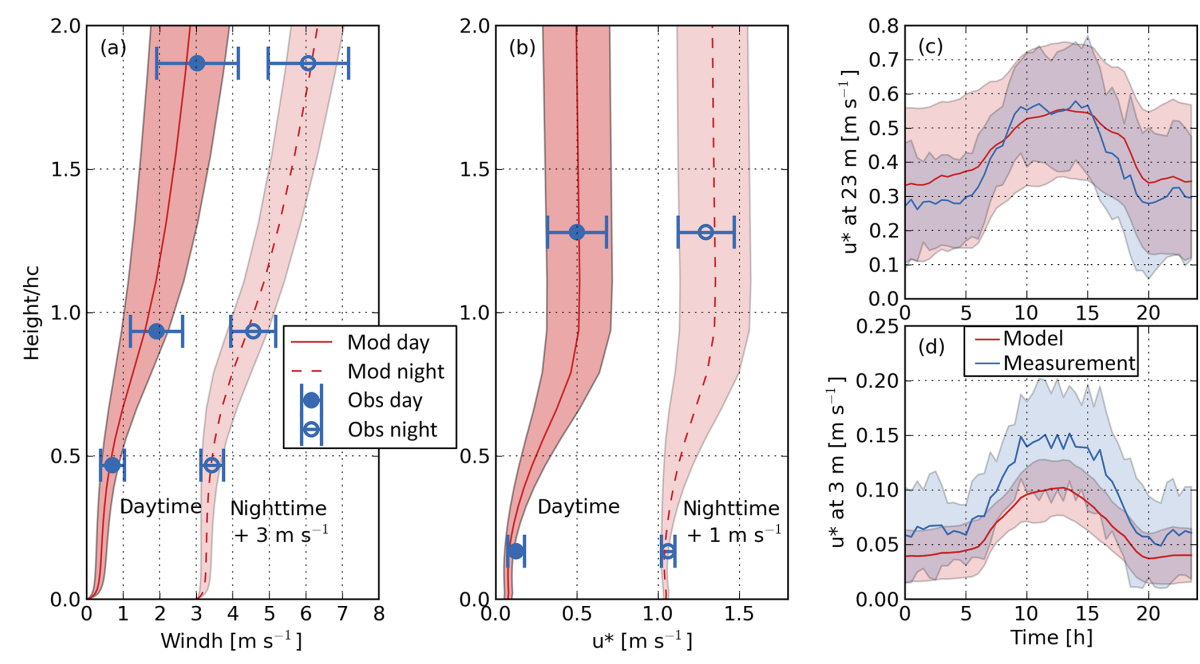

Figure 3. Modelled (red solid line for daytime, red dashed line for nighttime) and measured (blue solid circle for daytime, blue empty circle for nighttime) profiles of horizontal wind speed (windh) (a) and friction velocity $\left(u^{*}\right)$ (b). Nighttime values are shifted by 3 and $1 \mathrm{~m} \mathrm{~s}^{-1}$ for wind and $u^{*}$ for clarity of presentation, respectively. The ranges of $\pm 1 \mathrm{SD}$ (standard deviation) of modelled and measured data are marked as shades and error bars. The height is normalised by canopy height $h_{\mathrm{c}}$. The monthly-mean diurnal cycles of modelled (red) and measured (blue) friction velocity at 23 and $3 \mathrm{~m}$ are shown in (c) and (d). The ranges of $\pm 1 \mathrm{SD}$ are marked as shades in the same colours.

turbulent transport above and within the canopy as well as for the calculation of the quasi-laminar boundary layer resistance of leaves $\left(r_{\mathrm{b}}\right)$ at each canopy layer and the soil boundary layer resistance $\left(r_{\mathrm{bs}}\right)$. Figure $3 \mathrm{a}$ shows the good agreement between modelled and measured monthly-mean horizontal wind speed profiles during both daytime and nighttime. The wind speed decreases quickly inside the canopy due to canopy drag, then changes little below $0.5 h_{\mathrm{c}}$ until near the surface where wind speed varies logarithmically to zero on the surface. The model reproduces the diurnal cycle of $u_{*}$ but overestimates the nighttime values by $\sim 0.05 \mathrm{~m} \mathrm{~s}^{-1}$ in average above the canopy (Fig. 3c). Below the canopy crown at $\sim 3 \mathrm{~m}, u_{*}$ is underestimated by $\sim 0.02 \mathrm{~m} \mathrm{~s}^{-1}$ at nighttime and $\sim 0.05 \mathrm{~m} \mathrm{~s}^{-1}$ at daytime (Fig. 3d). The discrepancy is likely due to the limitation of representing the real heterogeneous dynamics by a 1-D model with homogeneous canopy configuration.

\subsection{PAR above and below the canopy crown}

PAR plays an important role in the stomatal exchange which determines to a large extent the daytime vegetation uptake. The PAR above the canopy is calculated directly from the measured incoming short-wave radiation serving as input to the model and shows a daytime maximum of about 250 $300 \mathrm{~W} \mathrm{~m}^{-2}$ during the simulation month. The PAR inside the canopy is calculated by considering the absorption, reflection and scattering effects of canopy leaves in the model (Sogachev et al., 2002). The comparison between modelled and observed PAR at $\sim 0.6 \mathrm{~m}$ below the canopy crown is shown in Fig. 4. The monthly-mean diurnal cycle of attenuated PAR below the canopy crown in the model is consistent with the observation except two missing peaks at daytime (Fig. 4b). These two peaks in the measurement are the consequence of direct exposure of PAR sensors to incoming solar radiation. 


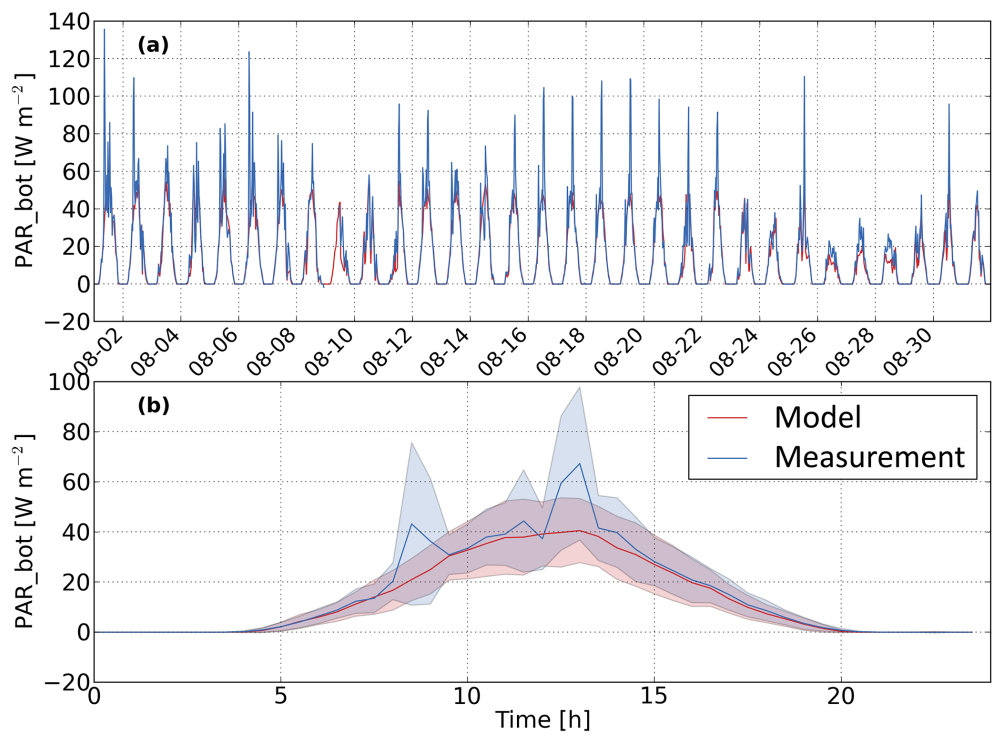

Figure 4. (a) Time series of PAR at $0.6 \mathrm{~m}$ from model (red) and measurement (blue) in August 2010. (b) The monthly averaged diurnal cycle of time series in (a) for model (red) and measurement (blue). The range of \pm 1 SD is marked by the shade with the same colour.

Such situation always occurs when point-wise measurement is compared with a model assuming a homogeneous forest canopy.

\subsection{Energy balance}

The monthly-mean diurnal cycles of sensible heat flux, latent heat flux, net radiation and soil heat flux are shown in Fig. 5 in order to verify the simulated energy balance above the canopy. The upward energy flux or the loss of surface energy is represented by positive values. During daytime, the soil and canopy loses energy by heat fluxes and gains energy mainly from net incoming solar radiation. At night, the surface loses energy by net upward long-wave radiation with an average rate of $\sim 33 \mathrm{~W} \mathrm{~m}^{-2}$, which is partly compensated by $\sim 20 \mathrm{~W} \mathrm{~m}^{-2}$ downward sensible heat flux.

During the simulation period the modelled diurnal cycles of energy fluxes agree well with the observation, although, for example, the latent heat flux is slightly underestimated by $\sim 30 \mathrm{~W} \mathrm{~m}^{-2}$ during daytime. In the afternoon from 14:00 to 20:00 LT, the sensible heat flux is underestimated by $\sim 20 \mathrm{~W} \mathrm{~m}^{-2}$. This could be explained by the underestimation in net radiation. However, the modelled values are generally within the 1 standard deviation range of the observations. The agreement between modelled and measured latent heat flux also indicates that the stomatal exchange, which controls the latent heat flux and is directly related to the stomatal resistance of $\mathrm{O}_{3}$ and many other gaseous compounds, is realistically simulated as a function of the meteorological drivers.

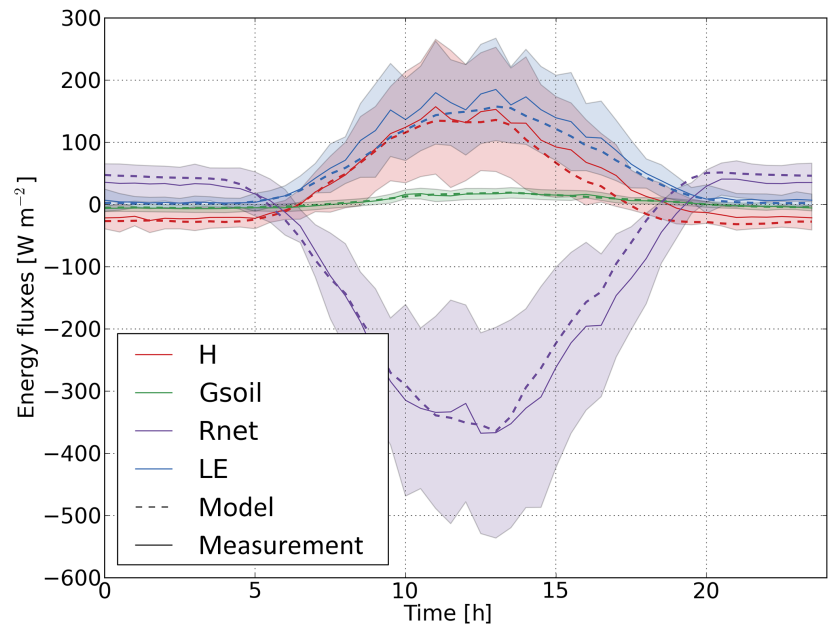

Figure 5. The monthly averaged diurnal cycle of different energy flux terms at $23 \mathrm{~m}$ above the ground for model (dashed lines) and measurement (solid lines), including sensible heat flux ( $H$, red line), soil heat flux ( $G_{\text {soil }}$, green line), upward net radiation $\left(R_{\text {net }}\right.$, purple line, note the observed $R_{\text {net }}$ is at $67 \mathrm{~m}$ ) and latent heat flux (LE, blue line). The range of \pm 1 SD for measurement data is plotted for every term by the shade with the same colour.

\section{$3.4 \quad \mathrm{O}_{3}$ fluxes}

The modelled time series of $\mathrm{O}_{3}$ turbulent flux and its diurnal cycle are compared with the measurement data above the canopy (Fig. 6). In general, the modelled flux shows a good agreement with the observations especially in the second half of month (Fig. 6a). Large discrepancies mostly occur in the first half of month, which is warm and dry. On the first 3 days 

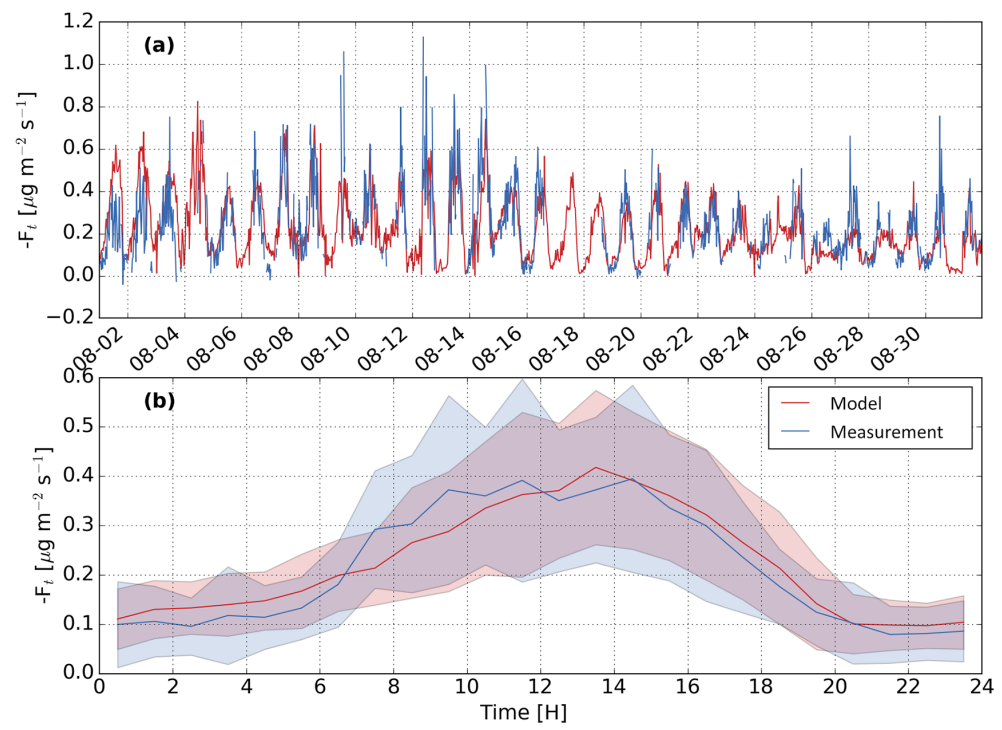

Figure 6. (a) Time series of the simulated (red) and measured (blue) $\mathrm{O}_{3}$ turbulent fluxes above the canopy in August 2010. (b) The monthly averaged diurnal cycles of time series presented in (a) for the model (red) and measurement (blue). The ranges of $\pm 1 \mathrm{SD}$ are marked by the shades with the same colours. Positive values represent downward fluxes.

of the month, the $\mathrm{O}_{3}$ turbulent flux is overestimated by the model. On some days at noon (e.g. 9, 12, 13, 14, 27, $30 \mathrm{Au}$ gust), the model is not able to predict the observed high peaks of $\mathrm{O}_{3}$ turbulent fluxes. In an average diurnal cycle of $\mathrm{O}_{3}$ turbulent flux the model does not capture the rapid increase of downward $\mathrm{O}_{3}$ turbulent flux in the morning, but it follows the measurement well after 10:00 LT. In general the agreement between the simulated and measured monthly-mean diurnal cycles of $\mathrm{O}_{3}$ turbulent fluxes is promising.

Figure 7 shows the correlation between the simulated and measured $\mathrm{O}_{3}$ turbulent fluxes above the canopy for different humidity conditions at daytime and nighttime separately. The overall $R^{2}$ between the modelled and measured $\mathrm{O}_{3}$ turbulent fluxes for the whole dataset is 0.47 . Among the four individual datasets under different conditions, the best prediction by the model occurs for the NH data points with $R^{2}$ of 0.37 , followed by the results reflecting the daytime high humidity conditions $\left(R^{2}=0.19\right)$. Note that these conditions with highest correlations are also the conditions with high $\mathrm{RH}$, especially at nighttime. All the correlations are significant $(p<0.001)$ except the condition NL for which $R^{2}$ is only 0.02 (Fig. 7). This indicates the difficulty of simulating the $\mathrm{O}_{3}$ turbulent flux in weak turbulence at nighttime. Usually at nighttime RH is larger than $70 \%$ (Fig. 2); under this condition ( $\mathrm{NH}$ condition), the wet skin uptake contributes more than $50 \%$ (Table 3) to the deposition flux. Therefore, the turbulent mixing above the ground which affects the deposition flux onto soil only plays a minor role on the deposition flux above the canopy. However, in NL condition, which does not happen frequently, nearly all the deposition inside the canopy is caused by soil deposition. Hence, the difficulty of simulating the exchange processes near the sur-

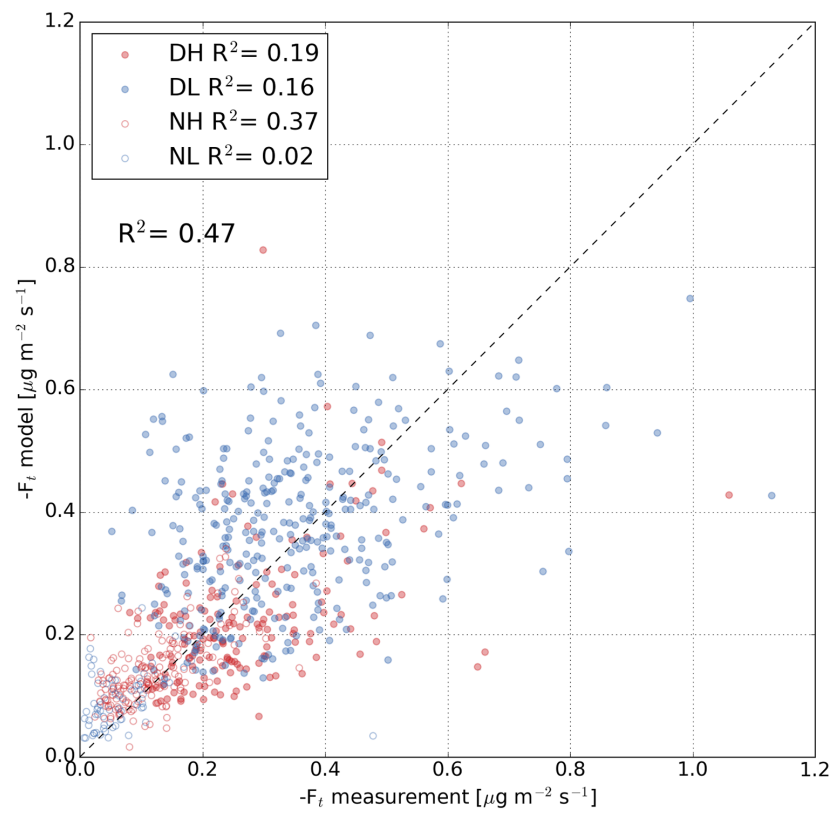

Figure 7. Scatter plots of modelled versus measured $\mathrm{O}_{3}$ turbulent fluxes above the canopy. The data points are plotted separately for different groups (DH, DL, NH and NL) with their $R^{2}$ values shown in the legend. $R^{2}$ of the whole dataset is shown below the legend.

face may cause more uncertainty of simulating the deposition flux onto soil surface under NL condition than NH condition. Moreover, the vertical advection of $\mathrm{O}_{3}$ could also affect the turbulent flux at nighttime (Rannik et al., 2009), which complicates the analysis. In contrast, there are only $69 \mathrm{ob}-$ served data points in the condition NL, which implies larger 


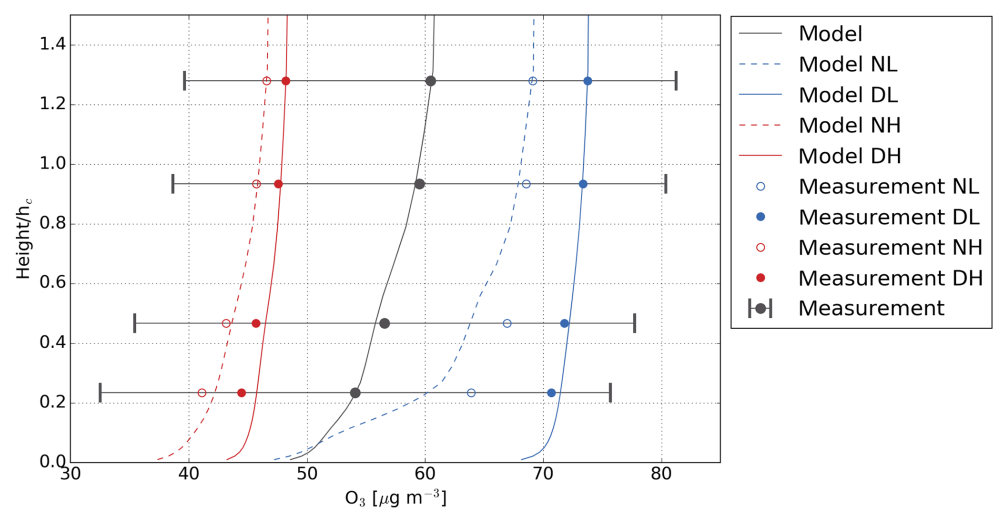

Figure 8. Measured average vertical profiles of $\mathrm{O}_{3}$ concentration for the whole month (dark grey, the horizontal bars are $\pm 1 \mathrm{SD}$ ) and individual conditions (daytime under high humidity condition, labelled as DH with red filled circle; daytime under low humidity condition, labelled as DL with blue filled circle; nighttime under high humidity condition, labelled as NH with red empty circle; nighttime under low humidity condition, labelled as NL with blue empty circle). Modelled results are plotted as solid lines (daytime) and dashed lines (nighttime) with the same colour as measurement. The height is normalised by the canopy height $h_{\mathrm{c}}$.

Table 3. The first four columns are the contribution fractions of different deposition pathways (stm as stomatal uptake, wet as wet skin uptake, cut as cuticle uptake, soil as soil surface uptake) in the integrated $\mathrm{O}_{3}$ deposition flux inside the canopy in the model. The last column is the sub-canopy (below $4.2 \mathrm{~m}$ ) $\mathrm{O}_{3}$ turbulent flux $\left(F_{\mathrm{t}, \text { mod }}(4.2 \mathrm{~m})\right.$ ) compared to the $\mathrm{O}_{3}$ turbulent flux above the canopy $\left(F_{\mathrm{t}, \mathrm{mod}}\right)$ in the model. Different conditions are listed along the row. $\mathrm{D}$ and $\mathrm{N}$ represent daytime and nighttime and $\mathrm{H}$ and $\mathrm{L}$ represent high and low humidity, respectively. ALL is for the whole dataset.

\begin{tabular}{lccccc}
\hline & Stm & Wet & Cut & Soil & $\begin{array}{c}F_{\mathrm{t}, \bmod }(4.2 \mathrm{~m}) / \\
F_{\mathrm{t}, \mathrm{mod}}\end{array}$ \\
\hline $\mathrm{D}$ & $63.0 \%$ & $3.79 \%$ & $1.12 \%$ & $32.1 \%$ & $38.0 \%$ \\
$\mathrm{~N}$ & $3.70 \%$ & $40.5 \%$ & $1.87 \%$ & $53.9 \%$ & $59.5 \%$ \\
$\mathrm{DH}$ & $47.2 \%$ & $18.5 \%$ & $0.94 \%$ & $33.4 \%$ & $39.6 \%$ \\
$\mathrm{DL}$ & $67.1 \%$ & $0.00 \%$ & $1.17 \%$ & $31.8 \%$ & $37.6 \%$ \\
$\mathrm{NH}$ & $3.28 \%$ & $51.0 \%$ & $1.04 \%$ & $44.7 \%$ & $51.4 \%$ \\
$\mathrm{NL}$ & $5.42 \%$ & $1.78 \%$ & $4.73 \%$ & $88.1 \%$ & $89.5 \%$ \\
$\mathrm{ALL}$ & $52.5 \%$ & $10.4 \%$ & $1.25 \%$ & $35.8 \%$ & $41.7 \%$ \\
\hline
\end{tabular}

random uncertainty. When the surface is wetter, the simulated nocturnal $\mathrm{O}_{3}$ turbulent fluxes correlate much better with the measurement. In addition, the measurement data show a larger range of variation (about $-1.2-0.0 \mu \mathrm{g} \mathrm{m}^{-2} \mathrm{~s}^{-1}$ ) compared to the range in the modelled $\mathrm{O}_{3}$ turbulent flux (about $-0.8-0.0 \mu \mathrm{g} \mathrm{m}^{-2} \mathrm{~s}^{-1}$ ), which implies that the model does not capture the $\mathrm{O}_{3}$ turbulent flux peaks or the measurements are more scattered due to random errors. Regarding the low $R^{2}$ values here, we should consider the uncertainty of measured fluxes. Such uncertainty contributes to the data scattering when comparing the modelled and measured fluxes, such as in Fig. 7, and reduces the correlation statistics.
In general, the parametrisation of wet skin fraction (Eq. 15) and its impact on $\mathrm{O}_{3}$ non-stomatal removal seems to represent the $\mathrm{O}_{3}$ deposition mechanisms inside the canopy well considering the good performance under high humidity conditions. Although the prediction of $\mathrm{O}_{3}$ turbulent flux with weak turbulence at night under low humidity condition still has large uncertainties (Fig. 7), the simulated average nocturnal $\mathrm{O}_{3}$ turbulent flux above the canopy shows a good agreement with the observation (Fig. 6b).

\section{5 $\mathrm{O}_{3}$ concentration profile}

In order to assess whether the good agreement between the observed and simulated $\mathrm{O}_{3}$ turbulent fluxes above the canopy also implies a realistic representation of the $\mathrm{O}_{3}$ concentration inside the canopy, we have conducted an evaluation of the simulated in-canopy $\mathrm{O}_{3}$ concentration profile. The 1-month averaged $\mathrm{O}_{3}$ concentration profiles from model results and measurements are shown in Fig. 8. The large variation range results from the meteorological variations in this month, especially the abrupt transition in the middle of the month (Fig. 2). The average $\mathrm{O}_{3}$ concentration of the whole month is $60.4 \mu \mathrm{g} \mathrm{m}^{-3}$ at $23 \mathrm{~m}$, then decreases gradually inside the canopy to $54.1 \mu \mathrm{g} \mathrm{m}^{-3}$ at $4.2 \mathrm{~m}$ due to the in-canopy sinks. Similar vertical gradients are also found for the four different conditions. At night, the turbulent mixing is weaker compared to daytime, which inhibits the downward transport of air with larger concentration of $\mathrm{O}_{3}$ into the canopy. Hence the $\mathrm{O}_{3}$ removal by canopy and especially by soil surface results in larger gradient of $\mathrm{O}_{3}$ inside the canopy during nighttime (Fig. 8).

The model results of $\mathrm{O}_{3}$ concentration profiles show a good agreement with the observations except the slight overestimation for the DH condition below $\sim 8 \mathrm{~m}\left(0.45 h_{\mathrm{c}}\right)$ and the apparent underestimation for the NL condition through- 


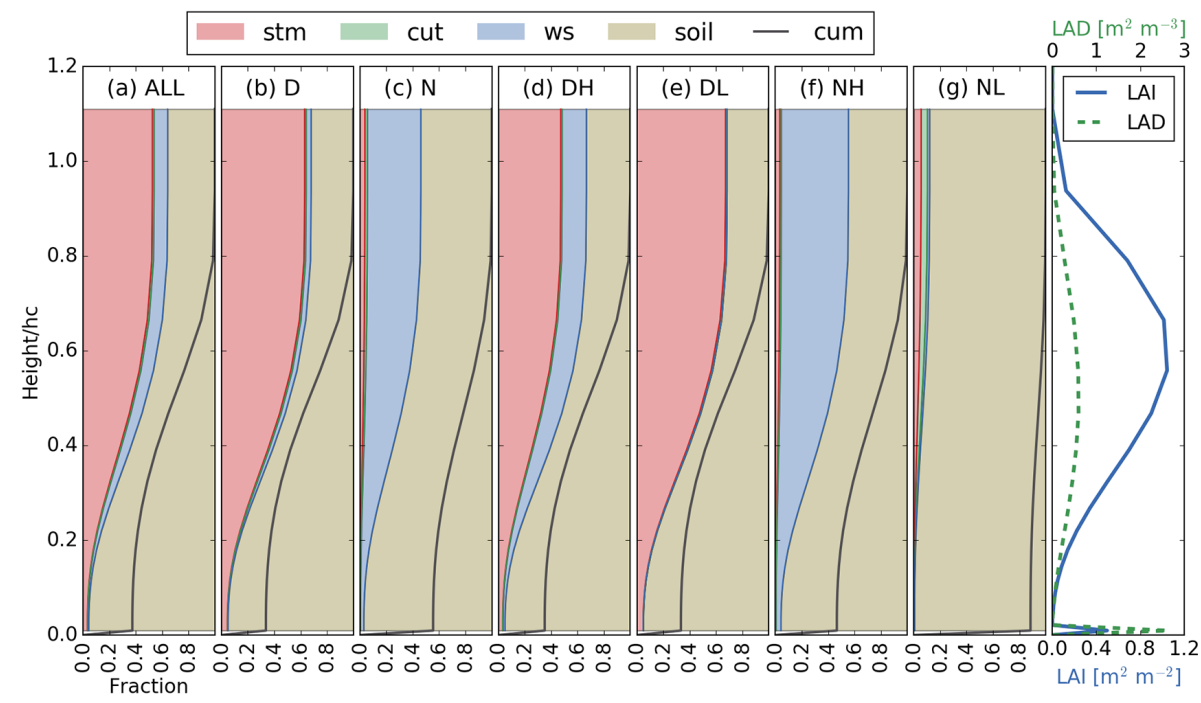

Figure 9. Simulated vertical profiles of cumulative $\mathrm{O}_{3}$ deposition flux normalised by the integrated $\mathrm{O}_{3}$ deposition flux above the canopy (cum, solid black line) for four conditions: DH (a), DL (b), NH (c) and NL (d). D and N represent daytime and nighttime and H and $\mathrm{L}$ represent high and low humidity, respectively. Shaded areas are the cumulative contribution fractions for different deposition pathways, including stomatal uptake (stm, red), cuticle uptake (cut, green), wet skin uptake (ws, blue) and soil uptake (soil, pale brown). The all-sided LAI profile for each layer and LAD is plotted again here (e). The height is normalised by the canopy height $h_{\mathrm{c}}$.

out the whole canopy. This is consistent with the model results of the $\mathrm{O}_{3}$ turbulent fluxes, which show $\sim 20 \%$ underestimation for the $\mathrm{DH}$ condition and $\sim 38 \%$ overestimation for the NL condition. In addition, the modelled vertical gradient of $\mathrm{O}_{3}$ concentration during nighttime at drier conditions (NL) is much larger inside the canopy compared to the measured gradient, which implies that the soil deposition is largely overestimated when the soil and dry vegetation surface uptake dominates the overall removal inside the canopy. This also indicates that further investigation is needed for the more accurate representation of ground surface deposition at different humidity conditions, including possibly the roles of uptake by the moss layer and soil humus layer.

\section{$3.6 \mathrm{O}_{3}$ flux profile}

The normalised cumulative $\mathrm{O}_{3}$ deposition flux at layer $i$ can be obtained as

$F_{\mathrm{c}, i}=\frac{\sum_{k=1}^{i} F_{k}}{\sum_{k=1}^{N} F_{k}}$,

where $F_{k}$ is the $\mathrm{O}_{3}$ deposition flux at layer $k$ and $N$ is the layer index just above the canopy. The profiles of $F_{\mathrm{c}}$ and the contributions of different deposition pathways for four different conditions are shown in Fig. 9. For the whole month, the $\mathrm{O}_{3}$ uptake is dominated by soil deposition below $0.2 h_{\mathrm{c}}$ $(\sim 3.6 \mathrm{~m})$ with only $\sim 8 \%$ contribution from the understorey vegetation via stomatal uptake. From 0.2 to $0.8 h_{\mathrm{c}}(\sim 14.4 \mathrm{~m})$ the cumulative uptake on leaf surfaces increases with height due to dense leaves in the plant crown area. Above $0.8 h_{\mathrm{c}}$ the remaining small portion of biomass $(\sim 7 \%)$ provides less than $2 \% \mathrm{O}_{3}$ uptake compared to the total $\mathrm{O}_{3}$ deposition.

The soil uptake contributes to the total $\mathrm{O}_{3}$ deposition flux at both daytime and nighttime (Fig. $9 \mathrm{~b}$ and c) with a percentage of $\sim 32$ and $\sim 54 \%$, respectively. At daytime, $\sim 63 \%$ of the $\mathrm{O}_{3}$ deposition flux is due to stomatal uptake, while at nighttime, when RH is larger than $70 \%$ at most of the time, the cumulative wet skin uptake contributes $\sim 41 \%$ to the total $\mathrm{O}_{3}$ deposition. At nighttime under high humidity conditions, the wet skin uptake even contributes $\sim 51 \%$ to the total $\mathrm{O}_{3}$ deposition fluxes (Table 3). This indicates that wet skin uptake plays a crucial role at night, which is consistent with the results in Rannik et al. (2012). As a result, the simulated averaged non-stomatal contribution to the integrated $\mathrm{O}_{3}$ deposition flux above the canopy is $\sim 37 \%$ during daytime and $\sim 96 \%$ during nighttime (Table 3 ). It should be noted that the stomata are not completely closed at night (Caird et al., 2007) and the minimum stomatal conductance at nighttime is about $5 \%$ of its maximum value at daytime (Kolari et al., 2007), which is similar with the simulation result here $(3.7 / 63.0 \% \approx 6 \%$, Table 3$)$.

Above $0.2 h_{\mathrm{c}}$, the stomatal uptake (DL, Fig. 9b), wet skin uptake $(\mathrm{NH}$, Fig. $9 \mathrm{c})$ or both of them (DH, Fig. 9a; NL, Fig. 9d) start to play a significant role in the cumulative $\mathrm{O}_{3}$ deposition fluxes. Hence at $0.8 h_{\mathrm{c}}$ the cumulative contribution of soil deposition is less than $50 \%$ except in the NL condition when both the cumulative stomatal uptake and wet skin uptake are limited. In all four conditions the dry cuticle 
uptake is minor with a maximum contribution of about $5.0 \%$ for the NL condition.

During daytime the sub-canopy layer, including soil surface, contributes about $38 \%$ to the integrated $\mathrm{O}_{3}$ deposition, which is consistent with the results from Launiainen et al. (2013) in which the sub-canopy (lower than $4.2 \mathrm{~m}$ ) contribution was $35-45 \%$ at daytime. At night the contribution increases to around $60 \%$ due to the closed stomata in crown layers. This is much higher than that $(25-30 \%)$ in Launiainen et al. (2013) (Table 3). The overestimation could result from the underestimation of the soil resistance, which is difficult to determine in such a complex ground ecosystem. However, among these four different conditions with the same constant soil uptake efficiency, only under the nocturnal dry conditions (NL) there is apparently an overestimation in $\mathrm{O}_{3}$ uptake and consequently underestimation of the $\mathrm{O}_{3}$ concentration inside the canopy (Fig. 8). Therefore, we expect that the poor performance for the NL condition also results from the limited data amount under this condition (only 69 data points), which leads to larger ratio of random uncertainty and thus smaller $R^{2}$.

Moreover, the assumption that the resistance $r_{\mathrm{ac}}$ between the understorey vegetation and ground is not a limiting factor for soil deposition might not hold under certain conditions. However, Launiainen et al. (2013) studied a period (1 July to 4 August 2010) 1-month earlier than the time period (1 to 31 August 2010) in this study, so the difference between these two studies could also be due to the meteorological and biological variations during the two summer months. However, the daytime contribution of the sub-canopy layer is consistent, so the difference between the 2 months could only play a minor effect.

\subsection{Contribution of air chemistry}

The role of chemical processes in explaining the $\mathrm{O}_{3}$ removal inside the forest canopy has been discussed in previous studies (e.g. Altimir et al., 2006; Wolfe et al., 2011; Rannik et al., 2012; Launiainen et al., 2013). A study by Wolfe et al. (2011) found that the non-stomatal uptake over a Ponderosa pine stand in the US was associated with additional very reactive BVOCs being present besides the identified ones. In contrast, Rannik et al. (2012) suggested that the air chemistry provided only minor contribution at SMEAR II. In order to estimate the contribution of chemical removal at SMEAR II, two different studies applied multi-layer models (Rannik et al., 2012; Launiainen et al., 2013) to simulate the $\mathrm{O}_{3}$ fluxes and concentration inside the boreal forest canopy. However, both of them showed their limitations on estimating the chemical contribution. Rannik et al. (2012) only considered one chemical reaction of $\mathrm{O}_{3}$ with $\beta$-caryophyllene. In Launiainen et al. (2013), they simplified the chemical production and loss of $\mathrm{O}_{3}$ with only two parameters to represent the first-order kinetic sink and photochemical production. In this study, we implemented a chemistry module with a detailed list of chemical reactions (see Sect. 2.4.1), which was able to provide a more accurate estimation of chemical removal of $\mathrm{O}_{3}$ inside the canopy.

In order to get rid of the effect of synoptic-scale transport of $\mathrm{O}_{3}$ and only focus on the local sinks and sources, we applied the simulation case FREEO3. In this simulation case we ignored the role of advection and only considered the role of local sources and sinks inside the canopy, i.e. dry deposition, chemical production and loss, and turbulent transport. Here the time period from 5 to 14 August were selected from the simulation results to analyse the local chemical contribution, because the modelled $\mathrm{O}_{3}$ concentration fit to the measurement the best during this period out of the whole month for the case FREEO3, which indicated that the advection also did not have an apparent effect on the local observed $\mathrm{O}_{3}$ variation. The daily averaged (from 5 to 14 August) production and loss of total $\mathrm{O}_{3}$ inside the canopy per square metre caused by dry deposition $\left(F_{\text {depo }}\right)$ and chemistry $\left(F_{\text {chem }}\right)$ are plotted in Fig. 10. Positive values correspond to $\mathrm{O}_{3}$ production and negative values represent $\mathrm{O}_{3}$ loss. Here the chemistry production is a net effect of $\mathrm{O}_{3}$ loss reactions and photochemical production. $F_{\text {depo }}$ (obviously negative) shows a maximum $\mathrm{O}_{3}$ loss rate at about 14:00 LT. The chemistry produces $\mathrm{O}_{3}$ from morning at $\sim 06: 00 \mathrm{LT}$ to the afternoon at $\sim 15: 00 \mathrm{LT}$ and destroys it throughout the other time of the day, especially at nighttime (Fig. 10). The ratio between $F_{\text {chem }}$ and $F_{\text {depo }}$ shows that chemical removal has its largest contribution of $\sim 9 \%$ of the dry deposition sink in average at nighttime from 20:00 to 04:00 LT. At daytime, our model simulation indicates that the $\mathrm{O}_{3}$ production caused by chemistry can compensate up to $\sim 4 \%$ of dry deposition loss in average. However, during the selected period, the chemical contribution and compensation can reach up to $\sim 24$ and $\sim 20 \%$ at most. This indicates that in general chemistry has minor impact on $\mathrm{O}_{3}$ alteration, but at some specific time the chemical production and removal of $\mathrm{O}_{3}$ can still play a significant role.

As a comparison, we also calculated the timescales of different removal processes to estimate the contribution of air chemistry. The average value of measured $\mathrm{O}_{3}$ flux $\left(F_{\mathrm{O}_{3} \text {,avg }}\right)$ in August 2010 above the canopy was $0.33 \mu \mathrm{g} \mathrm{m}^{-2} \mathrm{~s}^{-1}$ at daytime and $0.10 \mu \mathrm{g} \mathrm{m}^{-2} \mathrm{~s}^{-1}$ at nighttime whereas the $\mathrm{O}_{3}$ concentration $\left(\left[\mathrm{O}_{3}\right]\right)$ inside the canopy was about $61.6 \mu \mathrm{g} \mathrm{m}^{-3}$ during daytime and $50.5 \mu \mathrm{g} \mathrm{m}^{-3}$ at night. So the timescale of total $\mathrm{O}_{3}$ flux $\left(\tau_{\mathrm{O}_{3}}\right)$ could be obtained from

$\tau_{\mathrm{O}_{3}}=\left[\mathrm{O}_{3}\right] h_{\mathrm{c}} / F_{\mathrm{O}_{3}, \mathrm{avg}}$,

which was $\sim 3400 \mathrm{~s}(\sim 1 \mathrm{~h})$ for daytime and $\sim 9100 \mathrm{~s}$ $(\sim 2.5 \mathrm{~h})$ for nighttime. However, the total $\mathrm{O}_{3}$ reactivity $(y)$ at $18 \mathrm{~m}$ during a similar time period and at the same boreal forest station was calculated by Mogensen et al. (2015), which was $1.58 \times 10^{-5}$ and $1.67 \times 10^{-5} \mathrm{~s}^{-1}$ for noon and 02:00 LT at night. If the same values were assumed to be applicable also inside the canopy, the timescale of the $\mathrm{O}_{3}$ removal by chemistry $\left(\tau_{\mathrm{c}, \mathrm{O}_{3}}\right)$, 

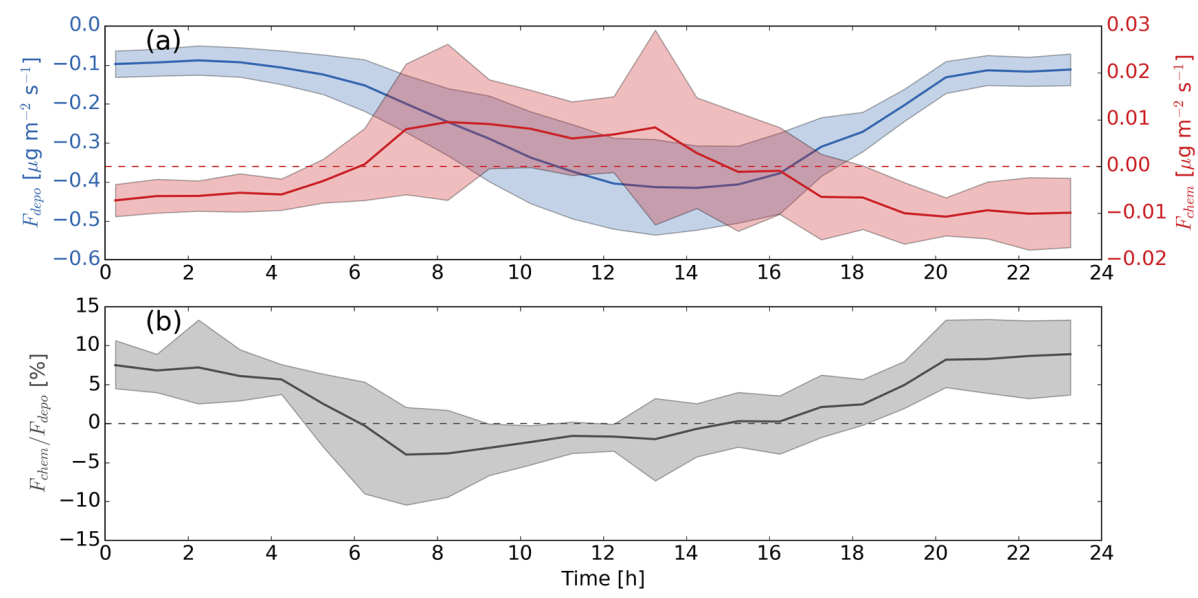

Figure 10. (a) The daily averaged (from 5 to 14 August) production and loss caused by chemistry $\left(F_{\text {chem }}\right.$, red) and dry deposition $\left(F_{\text {depo }}\right.$, blue). (b) The ratio between $F_{\text {chem }}$ and $F_{\text {depo }}$. Zero lines for $F_{\text {chem }}$ and the ratio are plotted as dashed lines. Shaded areas show the range of $\pm 1 \mathrm{SD}$.

$\tau_{\mathrm{c}, \mathrm{O}_{3}}=y^{-1}$

was $\sim 63300 \mathrm{~s}(\sim 18 \mathrm{~h})$ for daytime and $\sim 59900 \mathrm{~s}(\sim 17 \mathrm{~h})$ for nighttime. These estimates showed that the chemical removal accounted for about $5 \%$ (3400/63 300) and $15 \%$ (9100/59900) of the total $\mathrm{O}_{3}$ removal within the canopy at daytime and nighttime, respectively.

Compared to the simulation results, the timescale analysis could not reflect the photochemical production of $\mathrm{O}_{3}$ during daytime, and hence the estimation of net chemical effects is not possible with this method. For nighttime, the timescale analysis overestimates the average contribution of chemical removal by about $88 \%$ (15\% compared to $8 \%, 8 \%$ is obtained from $9 \% /(100 \%+9 \%))$. The comparison result could act as a proof of the statement in Wolfe et al. (2011), which argued that the timescale might not be a good criteria of chemical influence.

\section{Summary}

A detailed multi-layer $\mathrm{O}_{3}$ dry deposition model has been implemented into SOSAA to investigate the $\mathrm{O}_{3}$ uptake by canopy and soil surface at a boreal forest station SMEAR II. The presented detailed analysis of the $\mathrm{O}_{3}$ deposition processes for this site also quantified various removal processes, e.g. by the dry and wet cuticle, by stomatal uptake and by the soil surface.

In this model the fraction of wet skin on canopy leaves was parametrised according to $\mathrm{RH}$ values to analyse the potential role of canopy wetness on $\mathrm{O}_{3}$ deposition for both high and low humidity conditions. Moreover, the multi-layer model also enabled the study of deposition processes inside the canopy and the partitioning of $\mathrm{O}_{3}$ deposition fluxes between the canopy crown and sub-canopy. In this study, the model has been validated by comparing the modelled and measured $\mathrm{O}_{3}$ turbulent flux above the canopy and its concentration profile inside the canopy.

Further investigation has been done through a more indepth correlation analysis on $\mathrm{O}_{3}$ turbulent fluxes for nighttime and daytime under high and low humidity conditions. The simulated $\mathrm{O}_{3}$ turbulent fluxes above the canopy correlated reasonably well with the measurement for the whole month with $R^{2}$ of 0.47 ( $\left.p<0.001\right)$, which was also consistent with the plausible prediction of $\mathrm{O}_{3}$ concentration profile inside the canopy. The significant correlation $(p<0.001)$ also applied to the daytime humid and dry as well as nighttime humid conditions (DH, DL and $\mathrm{NH}$ ) with $R^{2}$ of $0.19,0.16$ and 0.37 . However, the model was not able to predict high peaks with $\mathrm{O}_{3}$ turbulent fluxes larger than $0.8 \mu \mathrm{g} \mathrm{m}^{-2} \mathrm{~s}^{-1}$. The model also did not capture well the measured $\mathrm{O}_{3}$ removal for the nocturnal dry condition (NL), in which $R^{2}$ was only 0.02 and the $\mathrm{O}_{3}$ concentration inside the canopy was largely underestimated (Figs. 7 and 8). The main reason could be the uncertainty of simulating the exchange processes near the ground in weak turbulent condition at nighttime when the soil deposition dominated the deposition flux inside the canopy.

Nearly all of the $\mathrm{O}_{3}$ uptake occurred below $0.8 h_{\mathrm{c}}$ inside the canopy. During daytime, the contributions of stomatal uptake $(\sim 47 \%)$, wet skin uptake $(\sim 19 \%)$ and soil uptake $(\sim 33 \%)$ were significant for the total $\mathrm{O}_{3}$ uptake under high humidity conditions, while under low humidity conditions the stomatal $(\sim 67 \%)$ and soil uptake $(32 \%)$ contributed dominantly the overall canopy deposition. During nighttime, the stomatal uptake contribution $(\sim 3 \%)$ was not zero but was much smaller compared to the wet skin uptake $(\sim 51 \%)$ under high humidity conditions. For the low humidity condition at night, nearly all the deposition $(\sim 88 \%)$ was due to soil uptake. Since RH was larger than $70 \%$ at most of the 
time during night, the uptake by wet canopy could be a dominant factor for the nocturnal $\mathrm{O}_{3}$ removal. In addition, the simulated non-stomatal contributions to the integrated $\mathrm{O}_{3}$ deposition fluxes were estimated as about 53,33, 97 and $95 \%$ for conditions DH, DL, NH and NL, respectively (Table 3).

The modelled contribution of sub-canopy deposition during daytime $(\sim 38 \%)$ was consistent with that (35-45\%) in Launiainen et al. (2013), but it was much higher at nighttime ( $\sim 60 \%)$ compared to that in the same study $(25-30 \%)$ (Table 3). This discrepancy at nighttime was most likely due to the overestimation of soil uptake.

The contribution of $\mathrm{O}_{3}$ removal by chemical reactions with currently identified BVOCs has also been evaluated. In general the air chemistry played a minor role in $\mathrm{O}_{3}$ uptake inside the canopy. In the simulated averaged diurnal cycle, the air chemistry produced $\mathrm{O}_{3}$ during daytime from about 06:00 to 15:00 LT, compensating up to $4 \%$ of dry deposition sinks, while at nighttime the chemical loss enhanced $\mathrm{O}_{3}$ removal by $\sim 9 \%$ of that by dry deposition. A qualitative estimation of chemical contribution with timescale analysis was also conducted as a comparison. However, this method overestimated the air chemical removal by about $88 \%$ for nighttime and it was not able to reflect the $\mathrm{O}_{3}$ production at daytime.
This study is the first step to establish a detailed gas dry deposition model in SOSAA. Further analysis of dry deposition will be done for other chemical compounds, especially for BVOCs. This will improve not only the ability to simulate air chemistry and aerosol processes but also our understanding of the mechanisms involved in the removal processes at boreal forest. In addition, it is also of scientific interest to investigate how future climate change might ultimately affect the removal processes of compounds like $\mathrm{O}_{3}$ and BVOCs for boreal forests.

\section{Data availability}

The model code of SOSAA and the output data of the simulations can be obtained by emailing Zhou Putian (putian.zhou@helsinki.fi). 


\section{Appendix A}

Table A1. Table of symbols.

\begin{tabular}{|c|c|c|c|}
\hline Symbol & Value & Unit & Description \\
\hline$h_{\mathrm{c}}$ & 18 & $\mathrm{~m}$ & canopy height \\
\hline LAI & & $\mathrm{m}^{2} \mathrm{~m}^{-2}$ & integral all-sided leaf area index, it can also represent the LAI at each layer in the context \\
\hline$T$ & & $\mathrm{~K}$ & air temperature \\
\hline$q_{v}$ & & $\mathrm{~kg} \mathrm{~m}^{-3}$ & specific humidity \\
\hline $\mathrm{RH}$ & & - & relative humidity \\
\hline$X$ & & - & scalar quantity \\
\hline$u_{*}$ & & $\mathrm{~ms}^{-1}$ & friction velocity \\
\hline$u_{* \mathrm{~g}}$ & & $\mathrm{~ms}^{-1}$ & friction velocity near the ground \\
\hline$H$ & & $\mathrm{~W} \mathrm{~m}^{-2}$ & sensible heat flux \\
\hline LE & & $\mathrm{W} \mathrm{m}^{-2}$ & latent heat flux \\
\hline$F_{\mathrm{t}, X}$ & & - & turbulent flux of $X$ \\
\hline$F_{\mathrm{t}}$ & & $\mu \mathrm{g} \mathrm{m}^{-2} \mathrm{~s}^{-1}$ & $\mathrm{O}_{3}$ turbulent flux \\
\hline$K_{\mathrm{t}}$ & & $\mathrm{m}^{2} \mathrm{~s}^{-1}$ & turbulent eddy diffusivity \\
\hline$K_{\mathrm{h}}$ & & $\mathrm{m}^{2} \mathrm{~s}^{-1}$ & turbulent eddy diffusivity for heat fluxes \\
\hline TKE & & $\mathrm{m}^{2} \mathrm{~s}^{-2}$ & turbulent kinetic energy \\
\hline$\varepsilon$ & & $\mathrm{m}^{2} \mathrm{~s}^{-3}$ & dissipation rate of TKE \\
\hline$\omega$ & & $\mathrm{s}^{-1}$ & specific dissipation of TKE \\
\hline$C_{\mathrm{p}, \text { air }}$ & 1009.0 & $\mathrm{~J} \mathrm{~kg}^{-1} \mathrm{~K}^{-1}$ & latent heat flux \\
\hline$\rho_{\text {air }}$ & 1.205 & $\mathrm{~kg} \mathrm{~m}^{-3}$ & air density \\
\hline$\gamma_{\mathrm{d}}$ & 0.0098 & $\mathrm{Km}^{-1}$ & lapse rate of dry air \\
\hline$L_{\mathrm{V}}$ & $2.256 \times 10^{6}$ & $\mathrm{~J} \mathrm{~kg}^{-1}$ & latent heat of vapourisation for water \\
\hline$C_{\mu}$ & 0.0436 & - & closure constant in calculating $K_{\mathrm{t}}$ \\
\hline$A_{\mathrm{s}}$ & & $\mathrm{m}^{2} \mathrm{~m}^{-3}$ & soil area index \\
\hline$Q_{\text {chem }}$ & & $\mu \mathrm{g} \mathrm{m}^{-3} \mathrm{~s}^{-1}$ & chemical production and loss \\
\hline$F$ & & $\mu \mathrm{g} \mathrm{m}^{-2} \mathrm{~s}^{-1}$ & $\mathrm{O}_{3}$ deposition flux \\
\hline$\left[\mathrm{O}_{3}\right]$ & & $\mu \mathrm{g} \mathrm{m}^{-3}$ & $\mathrm{O}_{3}$ concentration \\
\hline$V_{\mathrm{d}}$ & & $\mathrm{ms}^{-1}$ & layer-specific conductance for $\mathrm{O}_{3}$ \\
\hline$V_{\text {dveg }}$ & & $\mathrm{m} \mathrm{s}^{-1}$ & layer-specific leaf surface conductance \\
\hline$V_{\text {dsoil }}$ & & $\mathrm{ms}^{-1}$ & soil conductance \\
\hline$r_{\mathrm{veg}}$ & & $\mathrm{s} \mathrm{m}^{-1}$ & leaf surface resistance \\
\hline$r_{\mathrm{veg} 1}$ & & $\mathrm{~s} \mathrm{~m}^{-1}$ & leaf surface resistance to the side without stomata \\
\hline$r_{\text {veg2 } 2}$ & & $\mathrm{sm}^{-1}$ & leaf surface resistance to the side with stomata \\
\hline$r_{\mathrm{b}}$ & & $\mathrm{s} \mathrm{m}^{-1}$ & quasi-laminar boundary layer resistance over leaf surface \\
\hline$r_{\mathrm{ac}}$ & 0 & $\mathrm{~s} \mathrm{~m}^{-1}$ & $\begin{array}{l}\text { resistance of turbulent transport from the reference height of the understorey vegetation to } \\
\text { the soil surface }\end{array}$ \\
\hline$r_{\mathrm{bs}}$ & & $\mathrm{sm}^{-1}$ & soil boundary layer resistance \\
\hline$r_{\text {soil }}$ & 400 & $\mathrm{~s} \mathrm{~m}^{-1}$ & soil resistance \\
\hline$r_{\mathrm{stm}}$ & & $\mathrm{s} \mathrm{m}^{-1}$ & stomatal resistance \\
\hline$r_{\mathrm{stm}, \mathrm{H}_{2} \mathrm{O}}$ & & $\mathrm{s} \mathrm{m}^{-1}$ & stomatal resistance for water vapour \\
\hline$r_{\text {mes }}$ & 0 & $\mathrm{~s} \mathrm{~m}^{-1}$ & mesophyllic resistance \\
\hline$r_{\text {cut }}$ & $10^{5}$ & $\mathrm{~s} \mathrm{~m}^{-1}$ & cuticle resistance \\
\hline$r_{\mathrm{ws}}$ & 2000 & $\mathrm{~s} \mathrm{~m}^{-1}$ & wet skin resistance \\
\hline$f_{\text {wet }}$ & & - & fraction of wet skin \\
\hline$D_{\mathrm{H}_{2} \mathrm{O}}$ & $2.12 \times 10^{-5}$ & $\mathrm{~m}^{2} \mathrm{~s}^{-1}$ & molecular diffusivity of water vapour \\
\hline$D_{\mathrm{O}_{3}}$ & $1.33 \times 10^{-5}$ & $\mathrm{~m}^{2} \mathrm{~s}^{-1}$ & molecular diffusivity of $\mathrm{O}_{3}$ \\
\hline$\kappa$ & 0.41 & - & von Kármán constant \\
\hline$\delta_{0}$ & & $\mathrm{~m}$ & the height above ground where the molecular diffusivity is equal to turbulent eddy diffusivity \\
\hline$z_{*}$ & 0.1 & $\mathrm{~m}$ & the height under which the logarithmic wind profile is assumed \\
\hline Sc & 1.07 & - & Schmidt number for $\mathrm{O}_{3}$ \\
\hline
\end{tabular}


Author contributions. Putian Zhou implemented the deposition code into SOSAA, made the simulation runs, analysed the results and wrote the main part of this manuscript. Laurens Ganzeveld provided and developed the deposition code, suggested the concepts of manuscript structure, contributed to the micrometeorology part and the discussions related to $\mathrm{O}_{3}$ fluxes. Üllar Rannik contributed to the micrometeorology part, the discussions related to $\mathrm{O}_{3}$ flux measurements and the discussions in chemical removal processes. Luxi Zhou contributed to implementing the deposition code into SOSAA and configuration of simulation runs. Rosa Gierens contributed to the configuration of meteorology part in SOSAA and configuration of simulation runs. Ditte Taipale contributed to the discussions related to air chemistry and site description. Ivan Mammarella contributed to discussions related to $\mathrm{O}_{3}$ flux measurements. Michael Boy provided SOSAA code and the main concept and structure of this manuscript.

Competing interests. The authors declare that they have no conflict of interest.

Acknowledgements. This work was supported by Maj ja Tor Nessling funding, the Academy of Finland (projects 1118615 and 272041), CRAICC (Cryosphere-atmosphere interactions in a changing Arctic climate), eSTICC (eScience tools for investigating Climate Change in Northern High Latitudes) and FCoE (The Centre of Excellence in Atmospheric Science - From Molecular and Biological processes to The Global Climate). This work was also supported by institutional research funding (IUT20-11) of the Estonian Ministry of Education and Research, and the European Regional Development Fund (Centre of Excellence EcolChange). The authors also wish to acknowledge CSC - IT Center for Science, Finland, for computational resources.

Edited by: S. M. Noe

Reviewed by: three anonymous referees

\section{References}

Altimir, N., Kolari, P., Tuovinen, J.-P., Vesala, T., Bäck, J., Suni, T., Kulmala, M., and Hari, P.: Foliage surface ozone deposition: a role for surface moisture?, Biogeosciences, 3, 209-228, doi:10.5194/bg-3-209-2006, 2006.

Boy, M., Sogachev, A., Lauros, J., Zhou, L., Guenther, A., and Smolander, S.: SOSA - a new model to simulate the concentrations of organic vapours and sulphuric acid inside the ABL Part 1: Model description and initial evaluation, Atmos. Chem. Phys., 11, 43-51, doi:10.5194/acp-11-43-2011, 2011.

Boy, M., Mogensen, D., Smolander, S., Zhou, L., Nieminen, T., Paasonen, P., Plass-Dülmer, C., Sipilä, M., Petäjä, T., Mauldin, L., Berresheim, H., and Kulmala, M.: Oxidation of $\mathrm{SO}_{2}$ by stabilized Criegee intermediate ( $\mathrm{sCI}$ ) radicals as a crucial source for atmospheric sulfuric acid concentrations, Atmos. Chem. Phys., 13, 3865-3879, doi:10.5194/acp-13-3865-2013, 2013.
Bäck, J., Aalto, J., Henriksson, M., Hakola, H., He, Q., and Boy, M.: Chemodiversity of a Scots pine stand and implications for terpene air concentrations, Biogeosciences, 9, 689-702, doi:10.5194/bg-9-689-2012, 2012.

Caird, M. A., Richards, J. H., and Donovan, L. A.: Nighttime Stomatal Conductance and Transpiration in $\mathrm{C}_{3}$ and $\mathrm{C}_{4}$ Plants, Plant Physiol., 143, 4-10, 2007.

Dee, D. P., Uppala, S. M., Simmons, A. J., Berrisford, P., Poli, P., Kobayashi, S., Andrae, U., Balmaseda, M. A., Balsamo, G., Bauer, P., Bechtold, P., Beljaars, A. C. M., van de Berg, L., Bidlot, J., Bormann, N., Delsol, C., Dragani, R., Fuentes, M., Geer, A. J., Haimberger, L., Healy, S. B., Hersbach, H., Hólm, E. V., Isaksen, L., Kållberg, P., Köhler, M., Matricardi, M., McNally, A. P., Monge-Sanz, B. M., Morcrette, J.-J., Park, B.-K., Peubey, C., de Rosnay, P., Tavolato, C., Thépaut, J.-N., and Vitart, F.: The ERA-Interim reanalysis: configuration and performance of the data assimilation system, Q. J. Roy. Meteorol. Soc., 137, 553597, doi:10.1002/qj.828, 2011.

Fares, S., McKay, M., Holzinger, R., and Goldstein, A. H.: Ozone fluxes in a Pinus ponderosa ecosystem are dominated by nonstomatal processes: Evidence from long-term continuous measurements, Agr. Forest Meteorol., 150, 420-431, 2010.

Felzer, B. S., Cronin, T., Reilly, J. M., Melillo, J. M., and Wang, $\mathrm{X}$.: Impacts of ozone on trees and crops, Comptes Rendus Geoscience, 339, 784-798, 2007.

Ganzeveld, L. and Lelieveld, J.: Dry deposition parameterization in a chemistry general circulation model and its influence on the distribution of reactive trace gases, J. Geophy. Res., 100, 2099921012, 1995.

Ganzeveld, L., Lelieveld, J., and Roelofs, G.-J.: A dry deposition parameterization for sulfur oxides in a chemistry and general circulation model, J. Geophys. Res.-Atmos., 103, 5679-5694, doi:10.1029/97JD03077, 1998.

Ganzeveld, L., Bouwman, L., Stehfest, E., van Vuuren, D. P., Eickhout, B., and Lelieveld, J.: Impact of future land use and land cover changes on atmospheric chemistryclimate interactions, J. Geophys. Res.-Atmos., 115, d23301, doi:10.1029/2010JD014041, 2010.

Ganzeveld, L. N., Lelieveld, J., Dentener, F. J., Krol, M. C., Bouwman, A. J., and Roelofs, G.-J.: Global soil-biogenic $\mathrm{NO}_{x}$ emissions and the role of canopy processes, J. Geophys. Res., 107, ACH 9-1-ACH 9-17, doi:10.1029/2001JD001289, 2002a.

Ganzeveld, L. N., Lelieveld, J., Dentener, F. J., Krol, M. C., and Roelofs, G.-J.: Atmosphere-biosphere trace gas exchanges simulated with a single-column model, J. Geophys. Res., 107, ACH 81-ACH 8-21, doi:10.1029/2001JD000684, 2002b.

Gierens, R. T., Laakso, L., Mogensen, D., Vakkari, V., Beukes, J. P., Van Zyl, P. G., Hakola, H., Guenther, A., Pienaar, J. J., and Boy, M.: Modelling new particle formation events in the South African savannah, S. Afr. J. Sci., 110, doi:10.1590/sajs.2014/20130108, 2014.

Goldstein, A. H., McKay, M., Kurpius, M. R., Schade, G. W., Lee, A., Holzinger, R., and Rasmussen, R. A.: Forest thinning experiment confirms ozone deposition to forest canopy is dominated by reaction with biogenic VOCs, Geophys. Res. Lett., 31, 122106, doi:10.1029/2004GL021259, 2004.

Guenther, A., Karl, T., Harley, P., Wiedinmyer, C., Palmer, P. I., and Geron, C.: Estimates of global terrestrial isoprene emissions using MEGAN (Model of Emissions of Gases and Aerosols from 
Nature), Atmos. Chem. Phys., 6, 3181-3210, doi:10.5194/acp-63181-2006, 2006.

Hardacre, C., Wild, O., and Emberson, L.: An evaluation of ozone dry deposition in global scale chemistry climate models, Atmos. Chem. Phys., 15, 6419-6436, doi:10.5194/acp-15-64192015, 2015.

Hari, P. and Kulmala, M.: Station for Measuring EcosystemAtmosphere Relations (SMEAR II), Boreal. Environ. Res., 10, 315-322, 2005.

Junninen, H., Lauri, A., Keronen, P., Aalto, P., Hiltunen, V., Hari, P., and Kulmala, M.: Smart-SMEAR: on-line data exploration and visualization tool for SMEAR stations, Boreal Environ. Res., 14, 447-457, 2009.

Kampa, M. and Castanas, E.: Human health effects of air pollution, Environ. Poll., 151, 362-367, 2008.

Keronen, P., Reissell, A., Rannik, Ü., Pohja, T., Siivola, E., Hiltunen, V., Hari, P., Kulmala, M., and Vesala, T.: Ozone flux measurements over a Scots pine forest using eddy covariance method: performance evaluation and comparison with fluxprofile method, Boreal. Environ. Res., 8, 425-443, 2003.

Kolari, P., Pumpanen, J., Kulmala, L., Ilvesniemi, H., Nikinmaa, E., Grönholm, T., and Hari, P.: Forest floor vegetation plays an important role in photosynthetic production of boreal forests, Forest Ecol. Manage., 221, 241-248, 2006.

Kolari, P., Lappalainen, H. K., Hänninen, H., and Hari, P.: Relationship between temperature and the seasonal course of photosynthesis in Scots pine at northern timberline and in southern boreal zone, Tellus B, 59, 542-552, doi:10.1111/j.16000889.2007.00262.x, 2007.

Korhonen, H., Lehtinen, K. E. J., and Kulmala, M.: Multicomponent aerosol dynamics model UHMA: model development and validation, Atmos. Chem. Phys., 4, 757-771, doi:10.5194/acp-4757-2004, 2004.

Kulmala, L., Launiainen, S., Pumpanen, J., Lankreijer, H., Lindroth, A., Hari, P., and Vesala, T.: $\mathrm{H}_{2} \mathrm{O}$ and $\mathrm{CO}_{2}$ fluxes at the floor of a boreal pine forest, Tellus B, 60, 167-178, doi:10.1111/j.16000889.2007.00327.x, 2008.

Kurpius, M. R. and Goldstein, A. H.: Gas-phase chemistry dominates $\mathrm{O} 3$ loss to a forest, implying a source of aerosols and hydroxyl radicals to the atmosphere, Geophys. Res. Lett., 30, 1371, doi:10.1029/2002GL016785, 2003.

Kurtén, T., Zhou, L., Makkonen, R., Merikanto, J., Räisänen, P., Boy, M., Richards, N., Rap, A., Smolander, S., Sogachev, A., Guenther, A., Mann, G. W., Carslaw, K., and Kulmala, M.: Large methane releases lead to strong aerosol forcing and reduced cloudiness, Atmo. Chem. Phys., 11, 6961-6969, doi:10.5194/acp-11-6961-2011, 2011.

Lamaud, E., Carrara, A., Brunet, Y., Lopez, A., and Druilhet, A.: Ozone fluxes above and within a pine forest canopy in dry and wet conditions, Atmos. Environ., 36, 77-88, 2002.

Lammel, G.: Formation of nitrous acid: parameterisation and comparison with observations, Tech. Rep. REPORT No. 286, MaxPlanck-Institut für Meteorologie, Hamburg, 1999.

Launiainen, S., Katul, G. G., Grönholm, T., and Vesala, T.: Partitioning ozone fluxes between canopy and forest floor by measurements and a multi-layer model, Agr. Forest Meteorol., 173, 85-99, 2013.

Mammarella, I., Peltola, O., Nordbo, A., Järvi, L., and Rannik, Ü..: Quantifying the uncertainty of eddy covariance fluxes due to the use of different software packages and combinations of processing steps in two contrasting ecosystems, Atmo. Meas. Tech., 9, 4915-4933, doi:10.5194/amt-9-4915-2016, 2016.

Massman, W. J.: Toward an ozone standard to protect vegetation based on effective dose: a review of deposition resistances and a possible metric, Atmos. Environ., 38, 2323-2337, 2004.

Meyers, T. P.: The sensitivity of modeled $\mathrm{SO}_{2}$ fluxes and profiles to stomatal and boundary layer resistances, Water Air Soil Poll., 35, 261-278, doi:10.1007/BF00290935, 1987.

Mogensen, D., Smolander, S., Sogachev, A., Zhou, L., Sinha, V., Guenther, A., Williams, J., Nieminen, T., Kajos, M. K., Rinne, J., Kulmala, M., and Boy, M.: Modelling atmospheric OH-reactivity in a boreal forest ecosystem, Atmos. Chem. Phys., 11, 97099719, doi:10.5194/acp-11-9709-2011, 2011.

Mogensen, D., Gierens, R., Crowley, J. N., Keronen, P., Smolander, S., Sogachev, A., Nölscher, A. C., Zhou, L., Kulmala, M., Tang, M. J., Williams, J., and Boy, M.: Simulations of atmospheric $\mathrm{OH}, \mathrm{O}_{3}$ and $\mathrm{NO}_{3}$ reactivities within and above the boreal forest, Atmos. Chem. Phys., 15, 3909-3932, doi:10.5194/acp-15-39092015, 2015.

Nemitz, E., Sutton, M. A., Schjoerring, J. K., Husted, S., and Paul, W. G.: Resistance modelling of ammonia exchange over oilseed rape, Agr. Forest Meteorol., 105, 405-425, 2000.

Rannik, Ü., Kolari, P., Vesala, T., and Hari, P.: Uncertainties in measurement and modelling of net ecosystem exchange of a forest, Agr. Forest Meteorol., 138, 244-257, 2006.

Rannik, U., Mammarella, I., Keronen, P., and Vesala, T.: Vertical advection and nocturnal deposition of ozone over a boreal pine forest, Atmos. Chem. Phys., 9, 2089-2095, doi:10.5194/acp-92089-2009, 2009.

Rannik, U., Altimir, N., Mammarella, I., Bäck, J., Rinne, J., Ruuskanen, T. M., Hari, P., Vesala, T., and Kulmala, M.: Ozone deposition into a boreal forest over a decade of observations: evaluating deposition partitioning and driving variables, Atmos. Chem. Phys., 12, 12165-12182, doi:10.5194/acp-1212165-2012, 2012.

Rinne, J., Bäck, J., and Hakola, H.: Biogenic volatile organic compound emissions from the Eurasian taiga: current knowledge and future directions, Boreal Environ. Res., 14, 807-826, 2009.

Ruckstuhl, K. E., Johnson, E. A., and Miyanishi, K.: Introduction. The boreal forest and global change, Philos. T. Roy. Soc. Lond. B, 363, 2243-2247, doi:10.1098/rstb.2007.2196, 2008.

Seok, B., Helmig, D., Ganzeveld, L., Williams, M. W., and Vogel, C. S.: Dynamics of nitrogen oxides and ozone above and within a mixed hardwood forest in northern Michigan, Atmos. Chem.d Phys., 13, 7301-7320, doi:10.5194/acp-13-7301-2013, 2013.

Smolander, S., He, Q., Mogensen, D., Zhou, L., Bäck, J., Ruuskanen, T., Noe, S., Guenther, A., Aaltonen, H., Kulmala, M., and Boy, M.: Comparing three vegetation monoterpene emission models to measured gas concentrations with a model of meteorology, air chemistry and chemical transport, Biogeosciences, 11, 5425-5443, doi:10.5194/bg-11-5425-2014, 2014.

Sogachev, A.: A note on two-equation closure modelling of canopy flow, Bound.-Lay. Meteorol., 130, 423-435, 2009.

Sogachev, A., Menzhulin, G., Heimannn, M., and Lloyd, J.: A simple three dimensional canopy - planetary boundary layer simulation model for scalar concentrations and fluxes, Tellus B, 54, 784-819, 2002. 
Stocker, T. F., Qin, D., Plattner, G.-K., Tignor, M., Allen, S. K., Boschung, J., Nauels, A., Xia, Y., Bex, V., and Midgley, P. M.: IPCC, 2013: Climate Change 2013: The Physical Science Basis, in: Contribution of Working Group I to the Fifth Assessment Report of the Intergovernmental Panel on Climate Change, Cambridge University Press, Cambridge, UK and New York, NY, USA, 2013.

Wesely, M. L.: Parameterization of surface resistances to gaseous dry deposition in regional-scale numerical models, Atmos. Environ., 23, 1293-1304, 1989.

Williams, J., Crowley, J., Fischer, H., Harder, H., Martinez, M., Petäjä, T., Rinne, J., Bäck, J., Boy, M., Dal Maso, M., Hakala, J., Kajos, M., Keronen, P., Rantala, P., Aalto, J., Aaltonen, H., Paatero, J., Vesala, T., Hakola, H., Levula, J., Pohja, T., Herrmann, F., Auld, J., Mesarchaki, E., Song, W., Yassaa, N., Nölscher, A., Johnson, A. M., Custer, T., Sinha, V., Thieser, J., Pouvesle, N., Taraborrelli, D., Tang, M. J., Bozem, H., Hosaynali-Beygi, Z., Axinte, R., Oswald, R., Novelli, A., Kubistin, D., Hens, K., Javed, U., Trawny, K., Breitenberger, C., Hidalgo, P. J., Ebben, C. J., Geiger, F. M., Corrigan, A. L., Russell, L. M., Ouwersloot, H. G., Vilà-Guerau de Arellano, J., Ganzeveld, L., Vogel, A., Beck, M., Bayerle, A., Kampf, C. J., Bertelmann, M., Köllner, F., Hoffmann, T., Valverde, J., González, D., Riekkola, M.-L., Kulmala, M., and Lelieveld, J.: The summertime Boreal forest field measurement intensive (HUMPPA-COPEC-2010): an overview of meteorological and chemical influences, Atmos. Chem. Phys., 11, 10599-10618, doi:10.5194/acp-11-10599-2011, 2011.
Wolfe, G. M. and Thornton, J. A.: The Chemistry of AtmosphereForest Exchange (CAFE) Model - Part 1: Model description and characterization, Atmos. Chem. Phys., 11, 77-101, doi:10.5194/acp-11-77-2011, 2011.

Wolfe, G. M., Thornton, J. A., McKay, M., and Goldstein, A. H.: Forest-atmosphere exchange of ozone: sensitivity to very reactive biogenic VOC emissions and implications for incanopy photochemistry, Atmos. Chem. Phys., 11, 7875-7891, doi:10.5194/acp-11-7875-2011, 2011.

Wu, Y., Brashers, B., Finkelstein, P. L., and Pleim, J. E.: A multilayer biochemical dry deposition model 1. Model formulation, J. Geophys. Res.-Atmos., 108, ACH 1-1-ACH 1-12, doi:10.1029/2002JD002306, 2003.

Zhou, L., Nieminen, T., Mogensen, D., Smolander, S., Rusanen, A., Kulmala, M., and Boy, M.: SOSAA - a new model to simulate the concentrations of organic vapours, sulphuric acid and aerosols inside the ABL - Part 2: Aerosol dynamics and one case study at a boreal forest site, Boreal Environ. Res., 19, 237-256, 2014.

Zhou, L., Gierens, R., Sogachev, A., Mogensen, D., Ortega, J., Smith, J. N., Harley, P. C., Prenni, A. J., Levin, E. J. T., Turnipseed, A., Rusanen, A., Smolander, S., Guenther, A. B., Kulmala, M., Karl, T., and Boy, M.: Contribution from biogenic organic compounds to particle growth during the 2010 BEACHON-ROCS campaign in a Colorado temperate needleleaf forest, Atmos. Chem. Phys., 15, 8643-8656, doi:10.5194/acp-15-8643-2015, 2015. 